\title{
Fiscal Redistribution in Latin America Since the Nineteenth Century
}

\author{
Leticia Arroyo Abad and Peter H. Lindert
}

\section{Introduction}

Economic historians now know that inequality has not been a constant feature of the Latin American landscape since the original colonization by Spain and Portugal. Rather it has fallen and risen several times over the two centuries of independence, and the dawn of the twenty-first century has also brought a welcome slight retreat from extreme inequality. ${ }^{1}$ Why the movements, and why the differences between countries?

Fortunately, the dawn of this century has brought not only a slight reversal of earlier inequality trends in Latin America, but also a blossoming of research on the sources of income inequality in the region today, lead by the World Bank and other international development agencies. ${ }^{2}$ This impressive wave of research has delivered an important part of what was promised by a World Bank call to arms back in the 1970s. Under the Presidency of Robert McNamara, a Bank team co-published the often-cited Redistribution with Growth, outlining how developing countries could produce more and share it more equally, and generating research momentum on these themes. Redistribution told a parable of some wise pro-growth egalitarians (Korea, Sri Lanka, Taiwan), in contrast to four Latin American countries that failed

\footnotetext{
${ }^{1}$ See in particular Frankema, Has Latin America Always Been Unequal? (2009); Williamson (2010); the entire special issues of Revista de Historia Económica, 28, 2 (2010); and Abad (2013a, b). See also the downloadable data set on inequality from around the world, 1820-2000, referenced and explained in van Zanden et al. (2014).

${ }^{2}$ See DeFerranti et al. (2004), Lindert et al. (2006), Braceda et al. (2009), ECLAC (2010, 2012, 2014), Lustig et al. (2011), the World Bank's Aspire database, Public Finance Review (2014), and the Commitment to Equity project led by Professor Lustig.
}

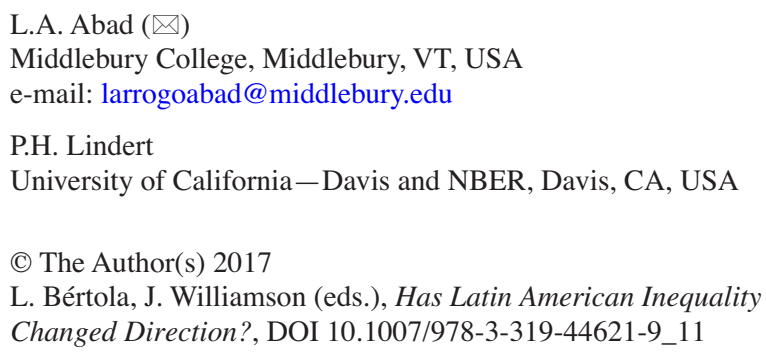


to follow this True Path. Brazil, Mexico, Panama, and Peru were characterized by some of the world's sharpest inequalities and not particularly strong growth. In later years, ECLAC $(1990,1992)$ and the World Bank study Inequality in Latin America: Breaking With History? explored the same questions more deeply. ${ }^{3}$

Did government fiscal preferences add to the inequality? That is, what distributional role has been played by movements in government fiscal policy, versus such market forces as changes in technological bias, trade expansion, shifts in labor supply, and shifts in the rate of private accumulation of human capital? For most of the two centuries of post-colonial history, inequality movements must have been caused largely by the ebb and flow of such larger forces outside of government, for the simple reason that government remained so small. Yet government's share of Latin American economies grew across the twentieth century and into the twenty-first, causing us to wonder how and when the region's regimes became "progressive" or "regressive" in their fiscal redistribution, breeding equality, or inequality.

The spate of recent studies suggests that countries' income inequalities in Latin America now differ as much from each other, and from inequalities in OECD countries on other continents, in their fiscal redistribution as in the pre-fisc original incomes they get from market forces. Among data-supplying countries, the Latin American countries stand out as the most unequal countries in terms of people's final incomes, partly because they have more unequal original incomes and partly because their governments redistribute less. ${ }^{4}$ Why have they had so little progressive redistribution lately, even after the much-heralded retreat from peak inequality? And has the same been true for a century or longer?

This chapter's strategy exploits the deep analysis of the twenty-first century distributional impact of fiscal policy, and uses it to explore episodes since the nineteenth century to initiate a history of fiscal incidence. We offer these tentative results:

(1) Social spending has accelerated in the postwar era: Tax-funded social spending has risen throughout the region since the 1980 s. $^{5}$

\footnotetext{
${ }^{3}$ Chenery et al. (1974), ECLAC (1990, 1992), and DeFerranti et al. (2004). Within the Redistribution with Growth study, most relevant for present purposes are Montek Ahluwalia's chapters on inequality and the policies for alleviating it (Chaps. 1 and 4). Its brief coverage of Cuba as of the early 1970s (pp. 262-268) identified this as an egalitarian experiment, but was guarded and inconclusive.

${ }^{4}$ This statement is based on a comparison of pre- and post-fisc inequalities in several countries in the first decade of this century. The sources are Lustig et al. (2011) for five Latin American countries, Buchele et al. (2013) for Uruguay, Sauma and Trejos (2014, Table 3, benchmark case) for Costa Rica, and Wang et al. (2012) for the rest. See these for the assumptions regarding fiscal incidence.

The estimates we are comparing here refer to the year 2004 with the following exceptions: Belgium-year 2000; Australia-2003; Sweden, France, and Israel-2005; Bolivia-2007; Chile-2008; Costa Rica 2010 and Argentina, Brazil, Peru, and Uruguay-2009. For alternative measures of the primary and final gini coefficients, 1979-2011, see Solt $(2009,2014)$.

${ }^{5}$ Like many of the statements in the literature and in this paper, this one must be read with the proviso "except for Cuba". Most comparisons have been forced to keep Cuba off to one side, for want of sufficient data. We will note Cuban results where we can.
} 
(2) The region invests little in its future today: Latin America redistributes less toward future generations than do other regions. Rather, the region is one of those, like Mediterranean Europe, where redistribution tilts away from investing in future generations and favoring the elderly in privileged formal sectors.

(3) It has invested relatively little in infrastructure and education ever since independence: Relative to other regions at comparable income levels, Latin America has invested less in its younger generations since the nineteenth century, and since the middle of the twentieth century it has favored its privileged seniors than other regions have done. Even before the 1990s, when public education was the main form of social spending, less was committed to mass education than in East Asia, East Europe, or the Middle East at similar levels of average income. In what follows we note some important historical exceptions to this rule.

(4) Progressivity has been meager. Aside from the Cuban Revolution, governments have redistributed only modestly, preferring a conflicted mix of "redistribution to the rich and the poor."6

(5) The rise of non-contributory public pension subsidies to retirees from the formal sectors stands out as a path-dependent legacy that will continue to retard progressivity and public investment. A telltale sign of the strength of this commitment is the design of the pension "reform" in Pinochet's Chile and the countries that sought to emulate it later.

(6) Chile has stood out, as a volatile, and initially regressive, redistributor since 1973. Redistributive policy was visibly regressive in the Pinochet era, both on the expenditure side and with a seemingly regressive tax structure. Yet since 1990 the net impact of its fiscal redistribution was slightly progressive in conventional Gini measures, because it benefited the rich less than their share of pre-fiscal income.

(7) Military autocracies differed in their redistributive strategies. Military rule periods did not affect redistribution in the same way in all countries. Unlike Chile (1973-1989), the junta in Uruguay (1973-1985) left the tax and social spending mix alone, at low absolute levels. Argentina's military rule (1976-1983) consolidated the social security system for most of the period, whereas Peru's military regime (1968-1980) was quite progressive.

(8) Human investments have brought more durable, though delayed, gains relative to transfers, both in the growth of GDP and in holding down inequality. In particular, Costa Rica has gained ground against Uruguay by emphasizing primary and secondary education over pensions.

(9) Social spending has been not only volatile but also pro-cyclical. Relative to GDP growth, annual changes in real social spending are at least two times or more variable. Moreover, they tend to follow the swings in economic activity. ${ }^{7}$

\footnotetext{
${ }^{6}$ This expression is borrowed from the title of Lindert et al. (2006).

${ }^{7}$ Clemens et al. (2007) have identified this pattern for 1990-2000s.
} 


\section{Strategies for Tracing a History of Fiscal Incidence}

Starting from the fiscal mix of this century and the distributional impacts on each household income quintile, we explore the implications of the historical movement in the fiscal mix. Like previous studies of fiscal incidence, ours uses imperfect and incomplete measures to provide insights into differences in progressivity and regressivity. These limitations are so strict that the fiscal incidence calculations are useful only as plausible suggestions about the direction of effect and the general orders of magnitude. As public finance textbooks warn their readers repeatedly, one should never imagine that all the possible effects of a particular set of budgetary flows have been worked out.

To be true to real-world budgetary processes and to pose interesting counterfactuals, one must weigh fiscal incidence on both the revenue side and the expenditure side, using a consistent definition of fiscal neutrality on both sides. Most studies have failed to do so. On the revenue side, studies of the progressivity (or regressivity) of taxation have typically assumed that the revenues are spent in proportion to pre-fisc original income, a rare outcome. On the expenditure side, studies of expenditure progressivity typically assume that the expenditures are financed by taxes that are fixed per person, another rare outcome. Real-world budgetary processes adjust revenues and expenditures together, requiring a two-sided measure of progressivity.

In Latin American history, the expenditure side of the fiscal coin reveals more about differences between countries, and also yields more data. On the revenue side, Kenneth Sokoloff and Eric Zolt have noted a strikingly consistent regional pattern: Latin America, more than any other region, relied on taxing domestic consumption, with little or no direct tax on individual incomes or property. Latin America also tended to concentrate fiscal authority more in the hands of the central government (Sokoloff and Zolt 2006). In what follows, we extract most of the information on differences in progressivity or regressivity from differences in the size and composition of social expenditures, rather than from differences in taxes or non-social expenditures.

To pose sensible counterfactuals about countries' fiscal incidence, the analysis should also make international comparisons. There should be little interest in comparing the actual fiscal patterns with the zero-government counterfactual, as in the presentation of most estimates. Rather we should compare governments' fiscal incidence with those of well-documented real-world alternatives, such as Chile or the USA. In our overview of the longer history of redistribution, we will take up the Chilean case first, and compare other countries to Chile.

\subsection{Redistribution Through Each Year's Social Spending and Taxes}

Governments channel their tax revenues into three kinds of expenditures: social spending, non-social spending, and debt reduction. The three have very different effects on the distribution of income. Estimating such effects requires figuring out 
which levels in the income ranks get more or less from each kind of expenditure and the revenues that back it.

The first effect is that of a given social spending budget. That is the traditional focus of much of the fiscal incidence scholarship, and it has been updated skillfully and energetically in the recent literature on Latin America. We shall pursue the same theme at length, taking care to include public spending on health and education as well as social transfers, while also incorporating tax incidence into the calculations of progressivity or regressivity when we can.

To define our measures of impact on the rich, the middle, and the poor, we start with a budget identity for government:

$$
\Sigma S_{i t}+\Sigma N_{j t}-D_{t}=\Sigma R_{k t}
$$

Here $S_{i t}=$ the amount of the $i$ th kind of social spending in time period $t$. Similarly, $N_{j t}$ is the amount of the $j$ th kind of non-social spending (general administration, police, the military, infrastructure, and so forth), and $R_{k t}$ is the $k$ th kind of government revenue (income tax, tariffs, other taxes, or income from government enterprises and assets). The revenues can cover less than the expenditures to the amount of $D_{t}$, this time period's government budget deficit. All magnitudes are in current prices. Later, to add economic meaning, they will be converted into per-household magnitudes and divided by national product or by an income class's average income.

The budget identity leads to measures of redistribution by following how the direct effects of spending and taxes on household incomes are divided among the five quintile ranks, from the poorest twenty percent of households $(q=1)$ to the richest $(q=5)$. Like most of the literature on fiscal incidence, we humbly acknowledge-and then ignore-all the serious reasons why these simple "flypaper" measures of redistribution fail to measure the full range of effects, including generalequilibrium effects through factor markets. To allocate each kind of social spending, and the taxes paying for it, across the income ranks, we define the benefits minus the costs for each quintile, or $B_{n e t, q i}$, as

$$
B_{n e t, q i t}=S_{i t}\left(b_{q i t}-c_{q i t}\right),
$$

where the five quintiles' shares of benefits add up to one, as do their shares of the revenue costs $\left(\sum_{q} b_{q i t}=1=\sum_{q} c_{q i t}\right) \cdot 8$

\footnotetext{
${ }^{8}$ Each is the result of two components that are not separated in our paper. One is the distribution of "benefits per recipient" in each quintile, and the other is "coverage," i.e., the number of persons in the quintile who receive any benefits at all. Incompleteness of coverage looms large in Latin America, and therefore affects the progressivity greatly: "Overall, about half of the population in LAC is not covered by any public transfer. Within the region, however, there is significant variation in coverage, with only $23 \%$ of Peruvian citizens not receiving any public transfer as compared with $73 \%$ of Mexicans without benefits" (Lindert et al. 2006, p. 23). Similarly, for each on the tax side, a quintile's tax burden is a combination of the tax collected person paying and the share paying any at all.
} 
To explore "effects" or "impacts," one must return to the familiar question of counterfactuals: "the effect of the observed budget-relative to what?" As we have already mentioned, the usual analysis unrealistically implies a zero-government alternative, because it tries to assign effects to the entire budget. To pose more realistic counterfactuals, we shrink the scale of the comparisons. We consider the social programs one by one, posing the counterfactual of removing that one real-world social program and the revenues that financed it, while leaving other social programs intact. Imagining a zero option for that one social program is not so unrealistic, since Latin America had done without most of these small social programs until just recently.

The other dimension of our implicit counterfactual about each social program hides within our phrase "and the revenues that pay for it." Which revenues? There is no point in imagining that all government revenues are at stake, since their amount far exceeds the social expenditures under discussion. Lacking any sound econometric estimates of which revenues increased at the margin when a given social program was introduced and expanded, we make a reasonable simplifying assumption about the revenues that would not have existed in the absence of each social program: For most of our historical measures, we assume that the same mix of revenue types would have held at the social program margin as we observe on the average. Thus if income tax were $16 \%$ of all government revenue, state monopoly proceeds were $6 \%$, indirect taxes were $70 \%$, and tariffs were the other $8 \%$, these same shares would be assume to apply to the scaled-down amount of the social expenditures in question. We do not assume any deficit finance of the social programs, in order to keep the issue of the deficit separate. ${ }^{9}$

To give the measures meaning as commitments to redistribution shares of income, we need to divide the absolute net benefit measures of $B_{\text {net,qit }}$ by an income denominator, also expressed in current prices. For convenience and brevity, we divide all quintile groups' benefit measures from social spending, whether gross or net of taxes, by the same common GDP denominator. We then compare such impacts on rich, middle, and poor income groups..$^{10}$

One other shortcut is dictated by data limitations. The net benefit measures change over time in response to changes in three components of any social program: the program's existence in a given year; its size as a share of national income; and its target efficiency, namely the extent to which it redistributes in favor of a particular group, usually the poor. We cannot pursue historical changes in the target efficiency of the social spending programs. Their history is just too complex and under-documented. Accordingly, our journey back into the redistributive history of social spending can only follow changes in the existence and size of each category

\footnotetext{
${ }^{9}$ In later writings, we will apply the same assumption to the revenues that finance non-social spending, such as military or infrastructure spending.

${ }^{10} \mathrm{~A}$ more common procedure is to divide all absolute redistributions to or from an income group by that same group's income. To trace a history of such measures, however, requires a running set of income distributions. No such time series is available before mid-twentieth century, apart from occasional benchmark years. The one virtuous exception consists of Javier Rodriguez Weber's time series on Chilean income inequality.
} 
of social spending, with the restrictive assumption that a given program had the same target efficiency in the past that it has today. This retreat is regrettable in large categories of social spending and taxation that kept the same name but shifted their progressivity or regressivity over time. As it happens, the Latin American history of fiscal redistribution limits the historical errors we commit by not following the changes in target efficiency over time. Many of the most progressive social programs did not exist before the 1980s, and have changed only a bit since. Also, the sizes of the individual social programs themselves capture most of the redistribution. We will also limit the loss from not knowing target efficiency by breaking up the historically dominant category of social spending, namely public education, into primary and secondary and tertiary education, which offer very different rewards to the different income ranks.

Fixing the target efficiency of social programs (again, the $i$ 's) at their present-day patterns means that our absolute measures of net fiscal benefits for any income class $(q)$ in years past (the variable $t$ 's) will be

$$
B_{n e t, q i t}=S_{i t}\left(b_{q i T}-c_{q i T}\right),
$$

where the " $T$ " subscript signals that the redistributive patterns ( $b$ 's and $c$ 's) are those from "today," usually a year at the start of the twenty-first century. In plainer words, our calculations of the fiscal incidence on different income classes will repeatedly ask The Question about any given year in the past:

The Question: How would the amounts of social spending programs, and the extra taxes that paid for them, have affected the incomes of the top, middle, and poorest income classes in that past year, if the benefits of those social programs, and those extra taxes, were distributed between income classes the way they are today?

In what follows we take advantage of the new information on how fiscal impacts are divided among quintiles to look not just at the movements of redistribution between rich and poor, but between rich and middle and poor, to explore the relationship of the "middle-income class" to the observed fiscal redistribution. When did the fiscal climate favor, or disfavor, the middle-income ranks relative to those at the top and bottom of society? To supplement the usual emphasis on overall inequality between rich and poor, we will break it into two parts, looking separately at movements in the fiscal treatment of the rich versus middle-income groups (top quintile vs. middle quintile) and at movements in the fiscal treatment of the middle and poorest groups (middle quintile vs. bottom quintile).

\subsection{Non-social Expenditures and the Deficit: Investment and Redistribution Over Time}

It would be tempting to explore how the different income ranks are affected by those other two kinds of public uses of funds: the government's non-social expenditures ( $N \mathrm{~s}$ in place of $S \mathrm{~s}$ ), or to the overall budget surplus. Unfortunately, the paucity of 
data on these incidences prevents our pursuing them in depth, and fixes our focus mainly on social spending and the revenues that pay for it.

Still, there is one major division within the non-social spending that has powerful redistributive meaning and is easy to document. Some kinds of non-social spending are investments that will clearly raise the incomes of future generations. If they are paid for by current taxes, these redistribute from older to younger generations. The most obvious examples are such infrastructure investments as transportation structures, public buildings, science centers, and experiment stations. Other kinds of non-social spending have a more questionable claim to being investments in future generations. Running a budget deficit similarly redistributes from future generations toward the current generation. While such inter-generational redistribution is not at all the usual focus of the now-conventional studies of "fiscal redistribution" within a single year, the inter-generational issue proves to have been a distinctive problem for Latin America, and we must confront it first, before launching a longer exploration of the redistributions that play out completely within 1 year.

\section{Today's Redistributive Patterns in Latin America}

The region redistributes income in distinctive ways. Before turning to today's richly documented patterns in social expenditures, let us first stay with the theme of the inter-generational redistributions implicit in the patterns of recent non-social spending. The simple redistributive pattern in non-social expenditures is one that carries over to the shares of human investments in social spending.

\subsection{Low Investment in Future Generations}

Perhaps the most pervasive kind of redistribution between parts of society in modern peacetime is the redistribution between present and future generations of adults. Governments, businesses, and households all decide what share of their current incomes should be borrowed from the future or invested in it. Borrowing from the future may or may not raise inequality, now and later, depending on economic growth and how the borrowed funds are spent.

Was Latin American policy worse at investing in the future than policy in other continents? When? What roles were played in investment setbacks like the Latin American debt crisis of 1982? And was the failure to invest especially bad in income-leveling types of human investments, such as public education for the masses?

The investment component of government spending is notoriously difficult to separate out in the data for most countries, blocking our view of how Latin America contrasts with other regions in public non-social investment. Our view is also clouded by the long-standing difficulty in resolving how private investment in the 


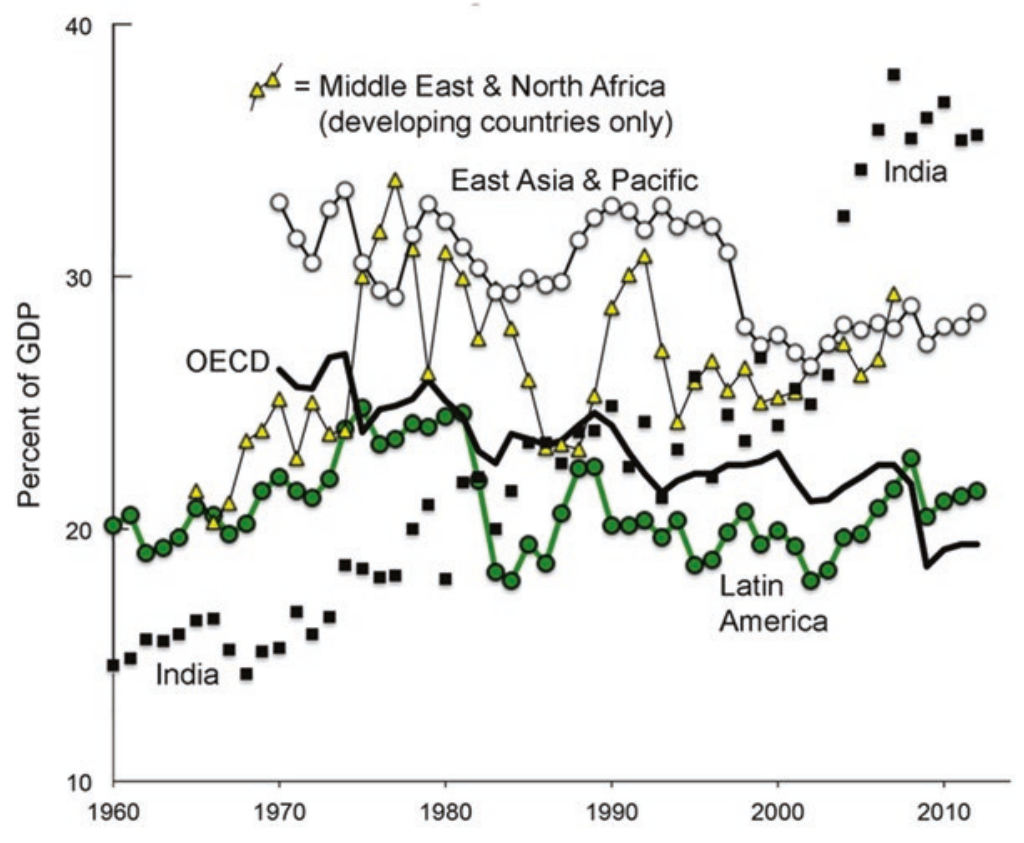

Fig. 1 Capital formation as share of GDP, World Regions, 1960-2012

future is affected by taxation and by government capital formation. Our best short route is to look at the official, and imperfect, measures of total private and public formation of non-human capital in the national product accounts. Taking this one step delivers a much clearer view of something distinctive about the region.

The best-known measure of a region's investing in the future is the share of national product that is channeled into forming non-human capital, both by private parties and by government. Ever since the 1960s we have been able to compare the private investment share for Latin America with the rest of the world's shares, with the results shown in Fig. 1. Latin America has consistently shown less sacrifice of current consumption for accumulating future assets than the world as a whole, and particularly less than East Asia and the developing countries of the Middle East and North Africa. ${ }^{11}$ Eastern Europe and Central Asia have also invested greater shares than Latin America, even in the austere 1990s, after the collapse of the Soviet Union and central planning. Granted, India had a lower investment share than Latin America from the 1960s to the debt crisis of the 1980s, when Latin America's investment rate was briefly the lowest among large regions; and granted, Africa South of the Sahara became the lowest-investing region from the late 1980s to the first decade of the twentieth century. Through it all, however, Latin America remained a below-average investor in future structures and equipment.

\footnotetext{
${ }^{11}$ The low investment share has already been underlined by United Nations, ECLAC (2012, p. 117).
} 


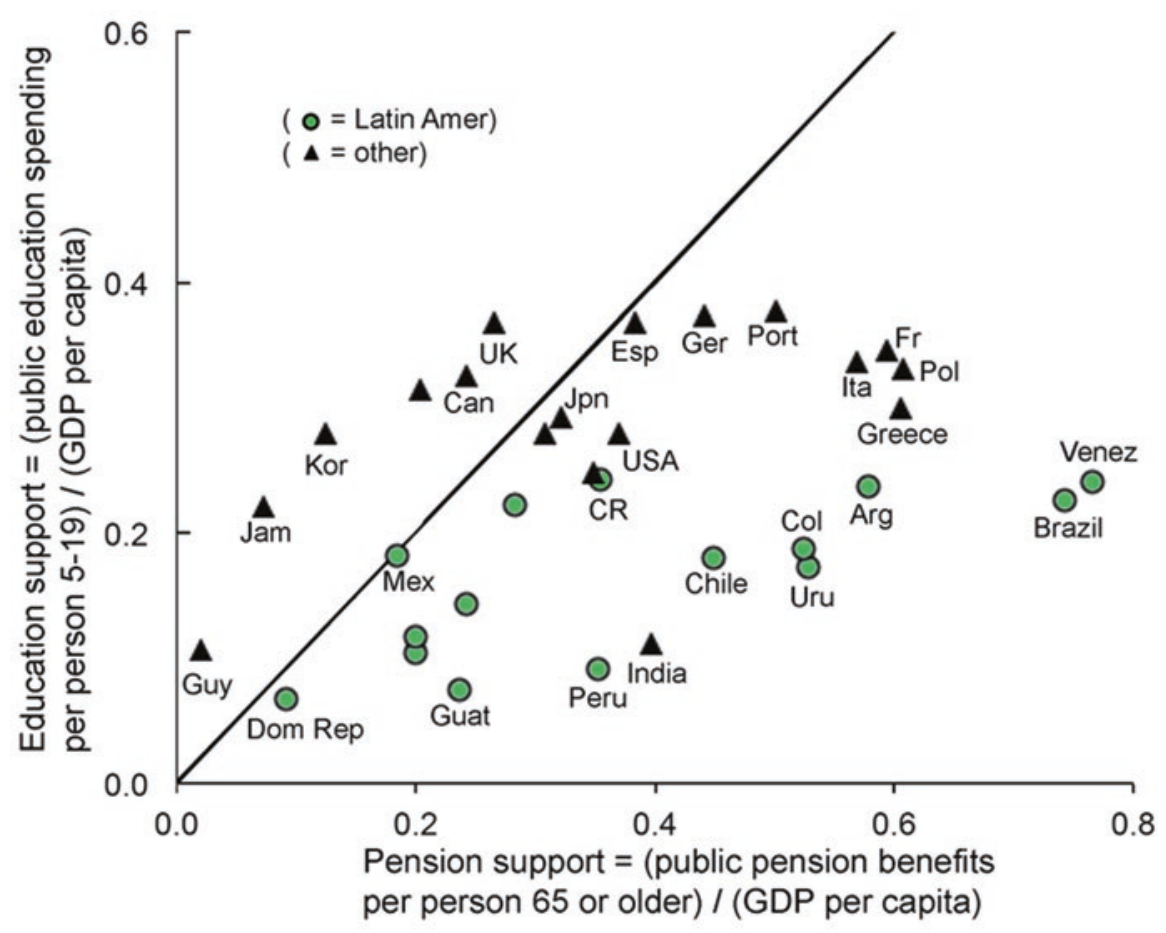

Fig. 2 Supporting pensions vs. education: Latin America vs. others, 2010

The region also invests little in human form. A cornerstone of modern growth has always been education in human skills and health. The traditional mechanism used by governments to promote such human development has been tax-based expenditures on formal education. Ever since the dawn of publicly funded mass education in Western Europe and its English-speaking offshoots in the nineteenth century, Latin American countries have lagged behind other regions, even where they had comparable incomes per capita and similar capacity for raising government revenue. ${ }^{12}$ Figure 2 and Table 1 underline this point with a present-day global snapshot. Latin American countries commit less to each child's public education than other countries, where commitment is reflected in the generosity of funding per schoolage child and the ability to pay for it is reflected in GDP per capita. ${ }^{13}$ Some countries

\footnotetext{
${ }^{12}$ For a quantitative historical overview of the region's disinclination to invest public money in mass schooling since 1870, see Lindert (2010). In terms of schooling outputs, its lagging behind all regions other than South Asia in the education attainment of adults since 1950 has been shown in Reimers (2006), Székely and Montes (2006, pp. 636-641), and Cohen and Soto (2007).

${ }^{13}$ In general, having lower average education expenditure per child of school age also tends to be correlated with having greater inequality in education inputs and education outcomes. To see this tendency within Latin America, compare the figures in Table 1 with the measure of inequality in educational attainment found in ECLAC (2014, pp. 78-79).
} 
Table 1 Supporting pensions versus educating the young: Latin America versus other countries, 2010

\begin{tabular}{|c|c|c|c|c|}
\hline & & & \multicolumn{2}{|l|}{ Support ratios } \\
\hline & \multicolumn{2}{|c|}{$\begin{array}{l}\text { Public spending as } \\
\text { a percent of GDP } \\
\text { pensions education }\end{array}$} & $\begin{array}{l}\text { Pension spending per } \\
\text { person } 65-\text { up, } / G D P \\
\text { per capita }\end{array}$ & $\begin{array}{l}\text { Education spending per } \\
\text { person 5-19/GDP per capita }\end{array}$ \\
\hline \multicolumn{5}{|l|}{ Latin America } \\
\hline Argentina & 7.4 & 5.8 & 0.58 & 0.24 \\
\hline Bolivia & 1.5 & 7.6 & 0.28 & 0.22 \\
\hline Brazil & 6.2 & 5.8 & 0.74 & 0.23 \\
\hline Chile & 5.0 & 4.2 & 0.45 & 0.18 \\
\hline Colombia & 3.5 & 4.8 & 0.53 & 0.17 \\
\hline Costa Rica & 2.8 & 6.3 & 0.35 & 0.24 \\
\hline Dominican Rep & 0.7 & 2.0 & 0.09 & 0.07 \\
\hline Ecuador & 1.8 & 4.2 & 0.24 & 0.14 \\
\hline El Salvador & 1.7 & 3.5 & 0.20 & 0.11 \\
\hline Guatemala & 1.2 & 2.8 & 0.24 & 0.08 \\
\hline Guyana & 0.1 & 3.7 & 0.02 & 0.10 \\
\hline Jamaica & 0.7 & 6.4 & 0.07 & 0.22 \\
\hline Mexico & 1.4 & 5.2 & 0.18 & 0.18 \\
\hline Paraguay & 1.2 & 3.8 & 0.20 & 0.12 \\
\hline Peru & 2.5 & 2.7 & 0.35 & 0.09 \\
\hline Uruguay & 8.8 & 4.2 & 0.53 & 0.19 \\
\hline Venezuela & 5.0 & 6.9 & 0.77 & 0.24 \\
\hline \multicolumn{5}{|l|}{ Other countries } \\
\hline Australia & 3.4 & 5.8 & 0.20 & 0.31 \\
\hline Canada & 4.2 & 5.5 & 0.24 & 0.33 \\
\hline France & 12.5 & 5.9 & 0.59 & 0.35 \\
\hline Germany & 10.7 & 5.1 & 0.44 & 0.37 \\
\hline Greece & 13.5 & 4.1 & 0.60 & 0.30 \\
\hline India & 2.2 & 3.3 & 0.40 & 0.11 \\
\hline Italy & 14.1 & 4.5 & 0.57 & 0.34 \\
\hline Japan & 8.8 & 3.8 & 0.32 & 0.29 \\
\hline Korea, Rep. & 1.6 & 5.1 & 0.12 & 0.28 \\
\hline Poland & 10.0 & 5.2 & 0.61 & 0.33 \\
\hline Portugal & 10.8 & 5.6 & 0.50 & 0.38 \\
\hline Russian Fed'n & 4.7 & 4.1 & 0.31 & 0.28 \\
\hline Spain & 8.0 & 5.0 & 0.38 & 0.37 \\
\hline UK & 5.4 & 6.2 & 0.27 & 0.37 \\
\hline USA & 6.0 & 5.4 & 0.37 & 0.28 \\
\hline Vietnam & 2.5 & 6.3 & 0.35 & 0.25 \\
\hline
\end{tabular}

Sources and notes for Table 1 and Fig. 2: Public pension expenditures as shares of GDP are taken from Pallares-Miralles et al. (2012, Annexes II and III), and based in turn on the World Bank Pensions Database. The latter source explicitly notes that their pension expenditure data included both contributory and non-contributory pension benefits, contrary to our preference for data on non-contributory only

Government education spending as a percent of GDP, 2010: Unesco 2013 estimates from http:// stats.uis.unesco.org/unesco/TableViewer

UN populations by age group, 2010:http://esa.un.org/wpp/ExcelData/population.htm, accessed 17 May 2013 
are reluctant to support anybody of any age group with taxpayers' money, as in the Dominican Republic or Guyana. Others support their average elderly person quite generously, yet still commit much less to each child of school age, two global extreme cases being Brazil and Venezuela. ${ }^{14}$ Whether the pension money goes to rich retirees or to poor ones is a question to be taken up shortly. The essential point, though, is that the share of income going into educating children for future earning power is lower in Latin America than elsewhere in the world.

\subsection{New Light on the Social Expenditure Side: Today's Redistribution to Rich and Poor}

What is now becoming clear about social expenditures comes to us mainly from some impressive team research efforts in The World Bank, the Inter-American Development Bank, and now the Commitment to Equity project headed by Nora Lustig. ${ }^{15}$ Taking advantage of the international agencies' vast accumulation of household surveys since the 1990s, these teams have been able to allocate the annual benefits from social programs among the different parts of the income spectrum, from the richest quintile (top $20 \%$ ) down to the poorest.

Table 2 displays what the international research teams have found about the "progressivity" or "regressivity" of distribution through different social expenditures in the decade 2000-2009. Our usual yardsticks for progressivity and regressivity of a public expenditure lie in the range between two popular assumptions about the taxes that pay for them. One assumption is an equal absolute tax, or foregone equal subsidy, on every household. This "poll tax" assumption divides the "clearly progressive" social programs of Table 2, in the left-hand column, from all the rest. Programs listed there on the left would prove to be progressive even if they were paid for by a (famously regressive) poll tax, a fixed amount of tax on each household. A more popular assumption, used by economists to define fiscal neutrality, is a flat percentage tax on all income or expenditure. This assumption divides the "clearly regressive" social programs, on the right-hand side of Table 2, from all the rest. The regressive ones are so tilted toward high-income recipients that they distribute benefits even more unequally than the distribution of pre-fisc original incomes, meaning that the distribution of final post-fisc incomes is even more unequal than the original distribution.

\footnotetext{
${ }^{14}$ Here, as will happen again in what follows, the measure of pensions is not the "redistributive" measure we seek. Rather we seek the amount of "non-contributory" payments for pensions, at the expense of the general taxpayer. All too often the available measures include pension benefits that are matched by the contributions of the employed, mixing such self-insurance in with true redistribution. Nonetheless, the available measures offer the right qualitative contrasts, even when they overstate the redistributive part of public pensions.

${ }^{15}$ DeFerranti et al. (2004), Lindert et al. (2006), Braceda et al. (2009), Lustig et al. (2011), Buchele et al. (2013), Sauma and Trejos (2014), and Public Finance Review (2014).
} 
Table 2 Progressive and regressive social spending programs, Latin American countries, 2000-2010

\begin{tabular}{|c|c|c|c|c|}
\hline & & \multicolumn{3}{|c|}{ Redistribution result (see notes for definitions) } \\
\hline \multicolumn{5}{|c|}{ "It depends": Regressive in \$ } \\
\hline & & Clearly progressive & $\begin{array}{l}\text { Progressive in } \\
\text { income shares }\end{array}$ & $\begin{array}{l}\text { Clearly } \\
\text { regressive }\end{array}$ \\
\hline \multicolumn{2}{|c|}{ Pensions, non-contributory part } & $\begin{array}{l}\text { Costa Rica, Chile } \\
\text { (PASIS) }\end{array}$ & $\begin{array}{l}\text { Chile (non- } \\
\text { PASIS), Mexico }\end{array}$ & $\begin{array}{l}\text { Colombia, } \\
\text { Guatemala, } \\
\text { Mexico }\end{array}$ \\
\hline Education & Pre-primary & $\begin{array}{l}\text { Bolivia, Brazil, } \\
\text { Colombia, Costa Rica, } \\
\text { Mexico, Peru, Uruguay }\end{array}$ & & \\
\hline$"$ & Primary & $\begin{array}{l}\text { Argentina, Bolivia, } \\
\text { Brazil, Costa Rica, } \\
\text { Mexico, Peru, }\end{array}$ & Guatemala & \\
\hline$"$ & Secondary & $\begin{array}{l}\text { Brazil, Costa Rica, } \\
\text { Peru }\end{array}$ & $\begin{array}{l}\text { Argentina, } \\
\text { Bolivia }\end{array}$ & \\
\hline$"$ & Tertiary & & $\begin{array}{l}\text { Bolivia, Brazil, } \\
\text { Costa Rica, } \\
\text { Mexico, Peru, } \\
\text { Uruguay }\end{array}$ & \\
\hline Health & & Uruguay, Mexico & Brazil & \\
\hline \multicolumn{5}{|c|}{ Consumption subsidies } \\
\hline$"$ & Food aid & $\begin{array}{l}\text { Costa Rica, Peru, } \\
\text { Uruguay }\end{array}$ & & \\
\hline$"$ & $\begin{array}{l}\text { Gas, electricity } \\
\text { subsidies }\end{array}$ & Bolivia & Mexico & \\
\hline$"$ & Housing & Mexico (some) & Mexico (some) & \\
\hline$"$ & $\begin{array}{l}\text { Transportation } \\
\text { subsidies }\end{array}$ & & Argentina & \\
\hline$"$ & $\begin{array}{l}\text { Agricultural } \\
\text { subsidies }\end{array}$ & & & Argentina \\
\hline ” & Airline subsidies & & & Argentina \\
\hline$"$ & Water, potable & Chile & & \\
\hline Family aid & & $\begin{array}{l}\text { Argentina, Brazil, } \\
\text { Colombia, Chile, Peru, } \\
\text { Uruguay }\end{array}$ & Bolivia & \\
\hline $\begin{array}{l}\text { Underemployment } \\
\text { compensation }\end{array}$ & & Argentina, Mexico & Brazil, Chile & \\
\hline $\begin{array}{l}\text { Conditional cash } \\
\text { transfers (CCTs), }\end{array}$ & & Argentina, Brazil, & & \\
\hline $\begin{array}{l}\text { mostly child } \\
\text { related }\end{array}$ & & Chile, Mexico & & \\
\hline
\end{tabular}

Sources and notes

The sources = Lindert et al. (2006), Lustig et al. (2011), Sauma and Trejos (2014, Fig. 6) and Buchele et al. (2013)

The definitions of redistribution results are

- "Clearly progressive" = Delivers more dollars per household to the poorer (lower quintiles) than to the richer. Thus it would be progressive even if financed by a poll tax 
Table 2 (continued)

- "It depends"=Regressive in \$, progressive in income shares=Fewer net dollars per household go to the poorer, but they receive a greater percentage of income than do the rich. It would be regressive if financed by a head tax, but progressive if financed by a flat percentage tax on income

- "Regressive" = The distribution of benefits favors the rich even more than the distribution of original (pre-fisc) income

Some cases that straddle the border between "clearly progressive" and "it depends" are some programs that work out as nearly flat in absolute $\$$ terms

- Argentine water and sanitation aid, and PAMI health

- Bolivia pensions

- Costa Rica health care and hospitalization

- Peru's two health subsidy programs (clearly progressive SIS health vs. ESSALUD health), and

- Uruguay secondary education

The results have rightly been summarized as "redistribution to the poor and the rich" among Latin America's social expenditure programs since around the year 2000. Many programs were meant to be progressive, shifting income from rich toward poor; yet some programs may not do so, and a few programs clearly redistribute toward the rich. The most clearly progressive programs are basic family assistance and "conditional cash transfers" (CCTs). The latter involve giving cash to poor parents (usually mothers) conditional on proof that their children were attending school and getting essential health care. The idea of means-tested CCTs was successfully invented and implemented in Brazil (bolsa familia, an extension of the previous bolsa escola) and Mexico (oportunidades, previously progresa). The clearly progressive CCTs have diffused to other countries in Latin America and to other continents.

In the case of public subsidies to education, the progressivity of subsidies depends on the level of education. Having the taxpayers pay for primary education clearly helps out lower-income families in nearly every country studied in the recent literature on redistribution. Yet government subsidies to tertiary education, such as university, are often not progressive. The students getting the subsidies tend to be from better-off families than the average taxpayers, given that most taxes in Latin America are levied on items of mass consumption. Thus the progressivity or regressivity subsidies to tertiary education "depends," as shown in Table 2, on whether the government paid for the subsidies by levying the same absolute tax on every household or by levying a fixed share of household income. ${ }^{16}$

Consumption subsidies vary widely between clearly progressive and clearly regressive. The result depends on whether the subsidized commodity is a necessity of life or a luxury. Table 2 illustrates this variability by contrasting the means-tested subsidies on essential foods (Costa Rica, Peru, Uruguay) and water (Chile) with the subsidies on airlines and agricultural estates (Argentina).

The impacts of public pension programs vary greatly, as Table 2 illustrates. Some are found to be clearly progressive (e.g., in Costa Rica, and Chile's PASIS

\footnotetext{
${ }^{16}$ Cases of regressive or near-regressive subsidies to higher education abound throughout the globe. For a pioneering demonstration of the likely regressivity of funding for the University of California, see the widely cited and controversial study by Lee Hansen and Weisbrod (1969).
} 
Table 3 Average net pension subsidies in the early twenty-first century

\begin{tabular}{l|l|l}
\hline Country & Data year & Net pensions subsidy (deficit share of total benefits paid out) (\%) \\
\hline Argentina & 2003 & 57 \\
\hline Brazil & 2003 & 40 \\
\hline Chile & 2002 & 56 \\
\hline Colombia & 2003 & 77 \\
\hline Dom. Repub. & 2001 & 0 \\
\hline Guatemala & 2000 & 25 \\
\hline Mexico & 2002 & 84 \\
\hline Peru & 2004 & 89 \\
\hline
\end{tabular}

Source and notes: The source is Lindert et al. (2006, p. 116)

For Brazil, pensions included (a) the system for private sector workers (RGPS) and (b) a system for public sector workers at the federal and sub-national levels of government (formerly RJU, then called RPPS). The deficit rates on these were averaged

For Chile, the authors used a weighted average of the $94 \%$ deficit on INP benefits and an assumed zero percent deficit on AFP benefits. The figures necessarily exclude military pensions, for which the deficit was a high share

For the Dominican Republic, the general policy was for all pensions to be covered by contributions, even though not on a same-year basis

Mexico $=$ weighted average for IMSS and ISSSTE

Peru $=$ weighted average for SNP and Cedula Viva

pension benefits), while others are clearly regressive in four countries, and still others are in between.

In reaching these conclusions, the research teams have taken special care to isolate the effects of those pension benefits that are truly redistributed from those that are not. What they have isolated in their recent studies, and what we must isolate as much as possible in the historical data, are the non-contributory parts of the public pension programs, the parts paid for by general taxpayers. We need to avoid counting the pension benefits that are paid for by contributions from the employees themselves and by their employers. These are just part of the labor contract, and not redistributions through the government's budgets. ${ }^{17}$ The recent wave of research has revealed some very large average shares of pension benefits not paid for by the recipients or their employers. Table 3 illustrates with recent information on pension program deficits as a share of the benefits paid. The researchers' judgment is that these are true non-contributory (deficit) shares, and not run-downs from past contributions. We return to the issue of pension deficits when exploring the quantitative history of each country's redistributive social spending.

The same kind of research on redistribution through social programs is extending around the globe. Some more global comparisons restricted to developing countries suggest a split in the Latin American degree of inequality reduction recently achieved by social protection and labor market programs. At the regressive end of

\footnotetext{
${ }^{17}$ In the case of pension benefits for government employees, whose employer is also the spender of tax revenues, redistribution cannot be identified just by looking at who paid the pensions. Rather one needs data on the deficit or underfunding of the public employee pensions, i.e., the amounts not covered by employer or employee contributions past or present.
} 
the scale, El Salvador, Paraguay, and Peru are among the few data-supplying countries with slightly regressive programs, ones that actually raise the Gini coefficient of inequality above that for original market incomes (along with Ghana, Rwanda, and Cambodia). Toward the more progressive end of the developing-country ranks are the four Southern Cone countries (ABC and Uruguay). Yet even these redistribute less progressively through their social programs than do the countries of the former Soviet zone.

Latin America's status as an unequal and not-so-progressive region would likely show up in the intergenerational immobility, as distinct from inequality, of its incomes if we had sufficient data comparing income mobility around the world. As a workable proxy for such income mobility, we have a global comparison of intergenerational mobility in years of schooling for the late twentieth century. Of the 42 countries studied, the seven Latin American countries studied had the least educational mobility from parents to children. Clearly, the region has formidable barriers to one's chances of changing ranks in education, given the position on one's parents. ${ }^{18}$ These barriers will soon reappear when we look at the restraints on the progressivity of public education finance.

Why is there so little redistribution in Latin America today? The near-null result has not emerged because of lack of scale, at least not for the whole region. In some Southern countries social spending has surpassed $20 \%$ of GDP, a threshold that could define a "welfare state." Rather, the politically implemented design of social spending and taxes is itself a mix of "redistribution to the rich and the poor," with inconsistent social targets.

\section{How Did This Happen?}

\subsection{The Evolution of Fiscal Mixes Since the Nineteenth Century}

We can easily see the overall net result of fiscal redistribution since Latin American countries gained their independence. Indeed, if we were content to take a single leap back to the historical horizon of 200 years ago, the net result is obvious. Back then there was essentially zero government, as in most countries around 1820 . The net changes over 200 years are simply the present-day patterns we have summarized in Table 1 and in Figs. 1, 2, and 3.

How did this happen? To know what forces have led to the present redistributions, and their limits, one needs to know the where and when. Narrative histories have painted an historical landscape filled with regime changes and clashes between

\footnotetext{
${ }^{18}$ See Hertz et al. (2007). To this list of 42 , Mexico has now been added, and has the 14th lowest educational mobility between generations out of 43 (Velez-Grajales et al. 2014), just below the USA (16th lowest). We have not yet been able to determine whether the research procedures were the same for the Mexican study as for the other 42 countries.
} 


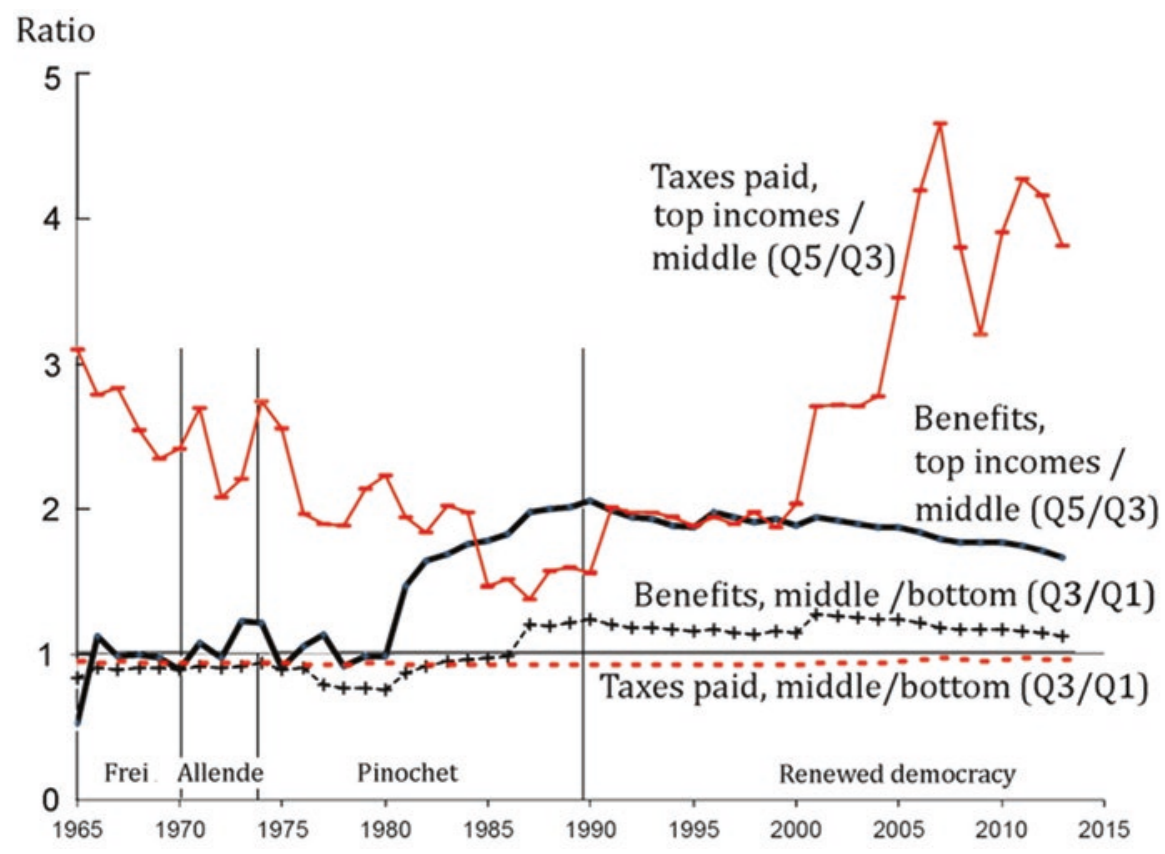

Fig. 3 Relative social spending benefits and tax burdens for Chile's top, middle, and bottom income classes, 1965-2013. Sources and notes: see Appendix 1

ethnic groups and special interests. New numbers can frame and support such paintings. We turn to the histories of some data-supplying countries, from which some patterns will emerge.

\subsubsection{Chile Since 1842}

Chile's experience with fiscal redistribution is the mostly richly documented, and in recent years the most dramatic and controversial, of all countries in the region, aside from the Cuban Revolution. We shall use the size of Chile's social budgets as a convenient baseline for commenting on the social spending efforts of each of our other five countries.

The rise of social spending as a share of GDP. Like the rest of the region since the 1960s, the central government of Chile has expanded social spending, a prime vehicle for fiscal redistribution, as shown in Table 4. And like the rest of the region, social spending evolved away from its being tiny and dominated by public education in the nineteenth century to devoting a rising share to transfers, especially pension payments, rather than to human investments like public education and public health. The annual detail behind Table 4, however, shows the instability of Chile's spending during the military dictatorship of Augusto Pinochet (1973-1989). Education spending 
Table 4 Social spending shares of GDP

\begin{tabular}{|c|c|c|c|c|c|}
\hline & \multicolumn{5}{|c|}{ Average social spending as $\%$ of GDP, current prices } \\
\hline & Public education & Public health & $\begin{array}{l}\text { Non-contributory public } \\
\text { pensions }\end{array}$ & Other & Total \\
\hline \multicolumn{6}{|c|}{ Chile, central government } \\
\hline 1842-99 & 0.40 & n.a. & 0 & 0 & 0.40 \\
\hline $1900-29$ & 1.08 & 0.03 & 0 & 0.03 & 1.14 \\
\hline 1930-39 & 1.94 & 0.56 & 0 & 0.17 & 2.67 \\
\hline $1940-49$ & 2.11 & 0.95 & 0 & 0.22 & 3.28 \\
\hline $1950-59$ & 2.15 & 1.31 & 0 & 0.11 & 3.57 \\
\hline 1960-73 & 3.60 & 1.93 & 0 & 0.91 & 6.44 \\
\hline 1974-79 & 3.40 & 2.42 & 0 & 8.44 & 14.27 \\
\hline $1980-89$ & 3.18 & 2.72 & 1.92 & 10.52 & 18.34 \\
\hline 1990-99 & 2.90 & 2.27 & 5.68 & 1.83 & 12.67 \\
\hline $2000-09$ & 3.68 & 2.99 & 6.71 & 0.62 & 14.00 \\
\hline $2010-13$ & 4.05 & 3.64 & 6.34 & 0.60 & 14.64 \\
\hline \multicolumn{6}{|c|}{ Argentina, central government } \\
\hline $1870-99$ & 0.07 & n.a. & 0.04 & n.a. & 0.11 \\
\hline $1900-29$ & 0.34 & n.a. & 0.09 & n.a. & 0.43 \\
\hline 1930-39 & 1.97 & n.a. & 0.44 & 0.32 & 2.74 \\
\hline $1947-49$ & 1.91 & n.a. & 0.41 & n.a. & 2.31 \\
\hline \multicolumn{6}{|c|}{ Argentina, central, provincial, and municipal } \\
\hline $1950-59$ & 1.95 & 1.10 & 1.50 & n.a. & 4.55 \\
\hline $1960-69$ & 2.45 & 1.35 & 1.75 & $\mathrm{a}$ & 5.55 \\
\hline \multicolumn{6}{|c|}{ Argentina, consolidated government } \\
\hline $1970-79$ & 3.55 & 1.95 & 5.22 & 4.62 & 15.33 \\
\hline $1980-89$ & 3.15 & 3.62 & 5.31 & 2.80 & 14.88 \\
\hline 1990-99 & 4.13 & 4.65 & 8.01 & 3.45 & 20.24 \\
\hline $2000-09$ & 5.09 & 4.80 & 7.42 & 4.36 & 21.67 \\
\hline \multicolumn{6}{|c|}{ Uruguay, central government } \\
\hline $1910-29$ & 1.20 & 0.96 & 1.30 & 0.01 & 3.47 \\
\hline 1930-39 & 1.56 & 1.27 & 3.99 & 0.05 & 6.87 \\
\hline $1940-49$ & 1.48 & 0.95 & 4.11 & 0.03 & 6.57 \\
\hline $1950-59$ & 1.56 & 1.12 & 5.44 & 0.15 & 8.27 \\
\hline 1960-69 & 2.81 & 1.29 & 6.73 & $\mathrm{a}$ & 10.84 \\
\hline 1970-79 & 2.63 & 1.79 & 8.48 & 0.37 & 13.27 \\
\hline $1980-89$ & 2.37 & 2.26 & 10.50 & 0.54 & 15.68 \\
\hline $1990-99$ & 2.25 & 3.02 & 12.03 & 0.84 & 18.14 \\
\hline $2000-08$ & 3.12 & 3.64 & 12.69 & 1.45 & 20.89 \\
\hline \multicolumn{6}{|c|}{ Costa Rica, central government } \\
\hline $1936-39$ & 1.37 & 0.48 & 0.22 & n.a. & 2.06 \\
\hline $1940-49$ & 1.52 & 0.49 & 0.30 & n.a. & 2.31 \\
\hline $1950-59$ & 1.44 & 0.29 & 0.39 & n.a. & 2.11 \\
\hline $1960-69$ & 2.83 & 0.40 & n.a. & n.a. & 3.23 \\
\hline
\end{tabular}


Table 4 (continued)

\begin{tabular}{|c|c|c|c|c|c|}
\hline & \multicolumn{5}{|c|}{ Average social spending as $\%$ of GDP, current prices } \\
\hline & Public education & Public health & $\begin{array}{l}\text { Non-contributory public } \\
\text { pensions }\end{array}$ & Other & Total \\
\hline 1970-79 & 3.00 & 0.32 & n.a. & n.a. & 3.32 \\
\hline \multicolumn{6}{|c|}{ Colombia, central government } \\
\hline $1905-29$ & 0.37 & n.a. & 0.00 & 1.12 & 1.49 \\
\hline 1930-39 & 0.33 & 0.27 & 0.00 & 0.95 & 1.55 \\
\hline $1940-49$ & 0.36 & 0.16 & 0.00 & 0.93 & 1.46 \\
\hline $1950-59$ & 0.52 & 0.31 & 0.00 & 1.33 & 2.17 \\
\hline $1960-69$ & 1.26 & 0.45 & 0.00 & 1.63 & 3.34 \\
\hline $1970-79$ & 2.12 & 0.91 & 1.73 & 1.32 & 6.08 \\
\hline $1980-89$ & 2.63 & 0.79 & 2.55 & 1.02 & 6.99 \\
\hline 1990-99 & 2.50 & 1.03 & 4.29 & 0.95 & 8.76 \\
\hline $2000-09$ & 3.04 & 1.88 & 5.84 & 0.42 & 11.19 \\
\hline $2010-13$ & 2.98 & 1.99 & 7.36 & 0.88 & 13.20 \\
\hline
\end{tabular}

Costa Rica, consolidated government

\begin{tabular}{l|l|l|l|l|l}
\hline $1980-89$ & 4.04 & 4.80 & 4.26 & 1.98 & 15.07 \\
\hline $1990-99$ & 4.06 & 4.66 & 4.53 & 1.82 & 15.06 \\
\hline $2000-09$ & 5.41 & 5.39 & 5.46 & 1.89 & 18.15 \\
\hline $2010-13$ & 7.17 & 6.56 & 6.62 & 2.28 & 22.63 \\
\hline
\end{tabular}

Peru, central government

\begin{tabular}{|c|c|c|c|c|c|}
\hline $1900-29$ & 0.08 & $\mathrm{~b}$ & $\mathrm{~b}$ & $\mathrm{~b}$ & 0.66 \\
\hline $1930-39$ & 0.38 & 0.21 & b & b & 1.14 \\
\hline $1940-49$ & 0.97 & 0.37 & $\mathrm{~b}$ & $b$ & 1.42 \\
\hline $1950-59$ & 1.92 & 0.43 & b & b & 2.48 \\
\hline 1960-69 & 3.85 & 0.97 & $\mathrm{~b}$ & b & 5.27 \\
\hline $1970-79$ & 3.48 & 1.00 & b & $\mathrm{b}$ & 4.99 \\
\hline 1980-89 & 2.57 & 0.99 & b & b & 4.00 \\
\hline 1990-96 & 2.43 & 0.89 & $\mathrm{~b}$ & $b$ & 3.86 \\
\hline
\end{tabular}

Peru, general government

\begin{tabular}{l|l|l|l|l|l}
\hline $1997-99$ & 3.13 & 1.25 & 2.55 & 0.59 & 7.52 \\
\hline $2000-09$ & 3.05 & 1.72 & 3.27 & 1.66 & 9.70 \\
\hline $2010-13$ & 3.01 & 2.24 & 2.41 & 1.79 & 9.45 \\
\hline
\end{tabular}

\section{Sources: See Appendix 1}

Notes

n.a = positive, but unknown and excluded from "other" and from "total"
(a) =included in pensions
(b) =included in total social spending

For each decade, the averages refer to the data-supplying years within that decade, sometime referring to fewer than 10 years

For the underlying annual data, see http://gpih.ucdavis.edu, folder on "Government budget historical series," under the heading "Latin American fiscal redistribution" 
gyrated, and pension spending gyrated even more. Let us first describe our resulting estimates of how these gyrations in overall social spending twisted the incomes of the rich, middle, and poorest income groups, before turning to our interpretation of the complex pension reforms that were at the center of the storm.

The distribution of social spending since 1965. How did social spending affect people in different income ranks? To answer this question requires the procedure we previewed above, in which we apply today's fiscal incidence of different social expenditures, and the average tax mix that is assumed to pay for them, to each year's social spending as a share of GDP. Table 5 summarizes the recent unit impacts

Table 5 Fiscal benefits and costs as shares of GDP for benchmark years

\begin{tabular}{|c|c|c|c|c|c|c|c|c|}
\hline & \multicolumn{4}{|c|}{ Social spending } & \multicolumn{3}{|l|}{ Taxes } & \multirow{2}{*}{$\begin{array}{l}\text { Benefits } \\
\text { minus } \\
\text { taxes }\end{array}$} \\
\hline & Education & Health & Pensions & All & Direct & Indirect & Total & \\
\hline \multicolumn{9}{|l|}{ Chile 1996-2000 } \\
\hline $\begin{array}{l}\text { Quintile 1 } \\
\text { (bottom) }\end{array}$ & 0.8 & 0.8 & 0.2 & 2.2 & 0.5 & 2.1 & 2.6 & -0.4 \\
\hline Quintile 2 & 0.8 & 0.7 & 0.5 & 2.3 & 0.5 & 2.0 & 2.5 & -0.2 \\
\hline Quintile 3 & 0.8 & 0.6 & 0.9 & 2.5 & 0.5 & 2.0 & 2.4 & 0.1 \\
\hline Quintile 4 & 0.8 & 0.4 & 1.7 & 3.1 & 0.5 & 2.0 & 2.5 & 0.6 \\
\hline Quintile 5 (top) & 0.7 & 0.2 & 3.1 & 4.9 & 1.0 & 4.0 & 5.0 & -0.1 \\
\hline All households & 3.9 & 2.7 & 6.4 & 15.0 & 2.9 & 12.1 & 15.0 & 0.0 \\
\hline \multicolumn{9}{|c|}{ Argentina 1999-2009 } \\
\hline $\begin{array}{l}\text { Quintile 1 } \\
\text { (bottom) }\end{array}$ & 1.8 & 2.4 & 4.4 & 9.6 & 0.0 & 1.6 & 2.6 & 7.0 \\
\hline Quintile 2 & 1.3 & 1.3 & 1.3 & 4.8 & 0.0 & 1.8 & 3.0 & 1.8 \\
\hline Quintile 3 & 1.0 & 0.8 & 1.1 & 3.7 & 0.0 & 2.2 & 3.7 & 0.0 \\
\hline Quintile 4 & 0.6 & 0.4 & 0.8 & 2.4 & 0.0 & 2.2 & 3.9 & -1.5 \\
\hline Quintile 5 & 0.2 & 0.1 & 0.2 & 0.9 & 4.5 & 2.1 & 8.3 & -7.3 \\
\hline All households & 5.0 & 5.0 & 7.9 & 21.4 & 4.5 & 9.8 & 21.4 & 0.0 \\
\hline \multicolumn{9}{|l|}{ Uruguay 2000} \\
\hline Quintile 1 & 1.8 & 2.1 & 11.5 & 16.4 & 0.4 & 4.3 & 4.7 & 11.6 \\
\hline Quintile 2 & 0.6 & 0.9 & 2.4 & 4.3 & 0.8 & 3.0 & 3.8 & 0.4 \\
\hline Quintile 3 & 0.3 & 0.5 & 0.8 & 1.8 & 1.2 & 2.6 & 3.8 & -2.0 \\
\hline Quintile 4 & 0.2 & 0.3 & 0.3 & 0.8 & 1.9 & 2.7 & 4.5 & -3.7 \\
\hline Quintile 5 & 0.1 & 0.1 & 0.1 & 0.3 & 4.1 & 2.6 & 6.7 & -6.4 \\
\hline All households & 3.0 & 3.8 & 15.0 & 23.5 & 8.3 & 15.2 & 23.5 & 0.0 \\
\hline \multicolumn{9}{|c|}{ Colombia 1966} \\
\hline Quintile 1 & 0.3 & 0.2 & & 0.5 & & & 0.1 & 0.4 \\
\hline Quintile 2 & 0.3 & 0.2 & & 0.6 & & & 0.2 & 0.4 \\
\hline Quintile 3 & 0.4 & 0.1 & & 0.5 & & & 0.3 & 0.2 \\
\hline Quintile 4 & 0.7 & 0.0 & & 0.9 & & & 0.5 & 0.3 \\
\hline Quintile 5 & 0.8 & 0.0 & & 1.0 & & & 2.5 & -1.4 \\
\hline All households & 2.6 & 0.5 & & 3.5 & & & 3.5 & 0.0 \\
\hline
\end{tabular}


Table 5 (continued)

Sources and notes

Our estimates actually use greater detail by social program than is shown in Table 5. For example, different unit impacts are applied for primary versus secondary versus tertiary education. See the Excel files within the Government Budget Historical Series folder of http://gpih.ucdavis.edu As noted in the text, the total taxes are equal to social expenditures, with the assumption that such expenditures are paid for in the same revenue-type proportions as in the aggregate budget

For Chile, the main sources are Engel et al. (1999), Lindert et al. (2006), Jorrat De Luis (2009), Rodriguez and Flores (2010), Cruz-Saco and Mesa Lago (1998, 69), and Acuña Rodrigo and Augusto Iglesias (2001, Table 5)

Note that for Chile the total social expenditures include more than the three subcategories (education, health, and pensions). Chile's tax incidence shares are from Engel et al. (1999), and refer to 1996. These shares of total revenue are applied to revenues and GDP for the year 2000

For Argentina the main sources are: Gasparini (1999), Sabaini et al. (2002), and Lustig et al. (2011). Note also that for Argentina the total tax revenues exceed the subcategories, due to inclusion of social security contributions. For Argentina's social security contributions, the quintiles paid these shares in 2000: Q1 paid $0.98 \%$ of GDP, Q2 paid 1.19\%, Q3 paid 1.57\%, Q4 paid $1.65 \%$, and Q 5 paid $1.73 \%$

For Uruguay, we lack a historical time series on social security taxes. We have, however, the estimated distribution of such taxes across quintiles. With this Uruguayan exception, we have included social security contributions separately in the revenues covering social expenditures. For the Uruguay estimates we had to allocate social security contributions to direct and indirect taxes, in the proportions assumed by the latter two

Around the year 2000, Uruguay's bottom quintile (Q1) paid 13.81\%, Q2 paid 16.74\%, Q3 paid $22.03 \%$, Q4 paid $23.21 \%$, and Q5 paid $24.20 \%$

For Colombia 1966, the main source is Berry and Urrutia (1976) Estimates covering the expenditure side for Colombia in 1974 can be found in Selowsky (1979). There were no public pensions in 1966

of each social program or tax on each of the five quintiles of households, in Chile and in three other countries. ${ }^{19}$

Concentrating on Chile's experience since 1965, Fig. 3 reveals the estimated effects on different ranks by following two kinds of ratios. The ratio of the social payments to households in the top income quintile to those in the middle quintile, or Q5/Q3, represents (one plus) the "upper gap" we introduced earlier, and the ratio of the payments to households in the middle and bottom quintiles (Q3/Q1) represents the "lower gap". During the military regime, the emphasis in social spending shifted in favor of the top $20 \%$ of the income ranks, and their advantage in such payments has persisted ever since, although it is slowly declining. The bulk of this increase consisted of rising pension benefits favoring higher income households, and the pension movements cry out for explanation.

Untangling the pension reforms of 1979-1981. The pension system set up by Chile's famous pension reform was, and still is, a huge share of annual GDP. To clear the way for understanding its effects, one should begin by noting that it is not what it

\footnotetext{
${ }^{19}$ Our estimates actually use greater detail by social program than is shown in Table 5. For example, different unit impacts are applied for primary versus secondary versus tertiary education. See the Excel files within the Government Budget Historical Series folder of http://gpih.ucdavis.edu.
} 
is often described to be. It was not a privatization of Social Security, as many have thought. There was no social security system to replace, but only a flawed and incomplete pension system for the privileged occupational groups of the formal sector. The reform also did not exactly privatize or liberalize pensions. It forced individuals to place pension contributions and benefits more firmly in the hands of the state and the private pension managing funds (AFPs) that the state appointed. It also raised the state's commitments and pension deficits, and these are projected to continue until 2045. Government pension spending, far from phasing out, truly soared.

The 1979-1981 pension reform needs to be understood as a system with these key features:

(1) The Pinochet regime inherited a badly broken and underfunded pension system in which formal sector workers were being subsidized. The regime chose to honor their underfunded entitlements by creating new government obligations to be covered by general taxpayers.

(2) The reform exempted the military from individualized forced savings or the defined-contribution feature. Military personnel continue to get generous net defined benefits from the taxpayers.

(3) To convert from defined benefit pensions to a defined-contribution system for civilians, the regime and its post-1989 successors have had to pay deficits to the transition generation. The deficits continue.

More specifically:

First, as mentioned, the previous system was badly broken, and the rise of unsustainable obligations was hidden from the official data of those pre-reform years. The occupational system for the more established formal-sector occupations, dating back to the 1920s, was increasingly mismanaged after about 1955 . What had been a contributory system that should have funded itself slid into deficit, as more and more employees evaded making contributions while keeping their benefit entitlements. Between 1955 and 1979 the ratio of contributors to pensioners fell from 12.2 to 2.5 , a result which cannot be explained by demographic trends, but rather resulted from allowing evasion of contributions while delivering generous benefits to those covered (Acuña Rodrigo and Augusto Iglesias 2001, p. 20).

For our accounting framework, this poses a huge problem of fiscal timing. As we had warned earlier, fiscal programs often give tax or benefit accruals in years that can be quite distant from the years of collection or payout. The 1979-1981 Chilean reform is perhaps the region's largest case of such a discrepancy. The obligations taken on in the 1980s in effect honored formal sector workers' evasion of pension contributions dating back to the 1950s, with benefits to be paid over subsequent years in ways that our studies have trouble tracking year by year. The military regime found itself inheriting a dilemma, one forcing it to choose between a shocking markdown of all occupational pension benefits and honoring the obligation to cover the full deficit. They chose the latter, with the result that the huge pension expenditures favoring higher-income beneficiaries suddenly show up in our graphs around 1975, even though they had secretly accrued over the previous two decades. 


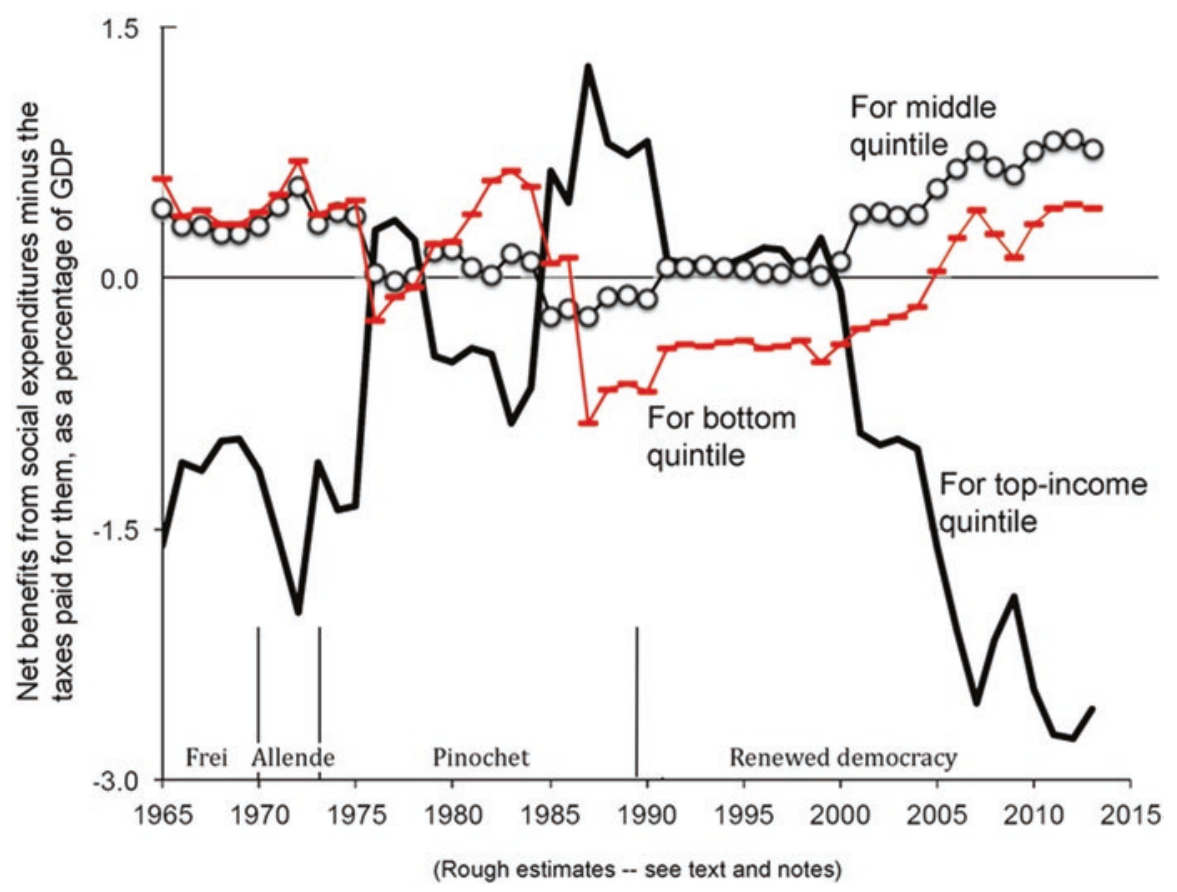

Fig. 4 Net benefits minus taxes paid, on social expenditure in Chile, 1965-2013. Sources and notes: see Appendix 1

Second, as we have noted, the Pinochet regime did not dare to slash military pensions, nor did it include them in the forced-saving reform, even when holding its firmest grip on power.

Third, like any change in pension regime that tightens up, in pursuit of eliminating deficits, Chile's new system faced the threat of double-taxing the transitional generation, forcing it to pay for the preceding generation's retirement while also paying for its own. Like the military exemption, this necessitated deficits lasting for a generation, from $8.4 \%$ of GDP in 1982 to $3.9 \%$ by the close of the century. ${ }^{20}$

At face value, the pension benefits suddenly became huge after the coup, and have stayed that way. In giving this impression Figs. 3 and 4 correctly portray what happened on an "accruals accounting" basis; yet they may mislead by portraying the movements as though the resources were paid out, in the cash accounting sense, at peak years like 1981-1986.

\footnotetext{
${ }^{20}$ One further drawback of the reform design was avoidable, rather than inherent. The Chilean AFP (private pension fund administrators) system levied charges that are widely agreed to have been exorbitant. "One quarter of net (of insurance fees) mandatory contributions of the average Chilean contributor who retired in 2000 went to administration fees." The fees loomed somewhat larger for lower earnings savers.
} 
To portray the level, and the distribution, of pension benefits correctly, we have taken care to use measures of just the redistributive, or non-contributory part of all pension payments. Again, the part covered by current contributions is not redistributive. For 1981 on, we can interpret the Acuña Rodrigo and Augusto Iglesias (2001, Table 5) social security deficit part of pension payments as the redistributive component. It was the "total social security deficit," most of which was the "transitory social security operational deficit," with much smaller amounts for Recognition Bonds and for the more permanent welfare and minimum pensions. ${ }^{21}$ The measures for the 1970s and earlier are less straightforward, for want of a clear measure of the pension deficit in those years. ${ }^{22}$

The deficit was huge, taking at least $8.4 \%$ of GDP in 1982, and still over $4 \%$ at the dawn of this century. Clearly, the transition from a broken and underfunded system to a fully funded "defined contributions" system was fiscally costly for Chile, as it has also proved for other countries imitating Chile's transition. It was also not progressive in Chile's case, since the beneficiaries of the deficit were, and still tend to be, upper income groups, largely the same formal sector groups that underpaid for their pension entitlements before the reform. ${ }^{23}$

Adding in the tax side. For Chile we have an opportunity to complete our counterfactual on the tax side. That is, there exist studies of how different kinds of taxes are distributed across the income groups "today," where today is the year 1996, thanks to Engel et al. (1999). Their article on "unpleasant redistributive arithmetic" derived Chile's distribution of direct taxes versus two kinds of indirect taxes in 1996, and we were able to apply their separate distributions to the shares of direct and indirect taxes back to 1965. This yields the distribution of taxes between high-, middle-, and low-

\footnotetext{
${ }^{21} \mathrm{Had}$ we instead used the "state subsidy to social security" share of GDP given by Cruz-Saco and Mesa-Lago (1998, p. 69), the estimates would have been slightly higher-e.g., $8.8 \%$ of GDP instead of $8.4 \%$ for 1982 , and $6.6 \%$ instead of $4.8 \%$ for 1993 .

${ }^{22} \mathrm{We}$ assume that before 1955 there was zero net deficit and zero redistribution. That is, we assume that the pre-1955 pensions in the public accounts were wholly contributory. Acuña Rodrigo and Augusto Iglesias (2001) note that there were many contributors per recipient then, but that the system fell apart under mismanagement until the Pinochet reforms. What to do about the years 19551981 ? It would seem natural to imagine a drop in the contributory share from 100 to $0 \%$ over these years. This would understate the rise in regressive redistribution toward the rich, since the official data on pension payments record only low out-payments in these years, and not the hidden buildup of obligations that were recognized only after 1981 . We have no choice but to go with the available data, using a current cash-flow approach and assuming that the out-payments occurred only from 1981 on. Much post-1981 regressivity actually accrued earlier. For 1976-1980, we interpret the "otros funciones sociales" as fully non-contributory and as regressive as the non-PASIS pensions at the end of the century. From 1981 on, we apply the Acuña-Iglesias social security deficit as the noncontributory part of both social security (previsión) and "other social programs."

Note that these pension payments and the special "otras funciones sociales" payments remain outside the usual calculations of annual disposable or final income in the year in which they are paid by the government. They trickled into benefits in earlier years in the case of pensions, and possibly later years for other programs.

${ }^{23}$ The quantitative embodiment of this statement is that for the pension recipients' payments out of the deficit we used the quintile shares estimated for Chile's non-PASIS pensions in Lindert et al. (2006, Tables 7 and 8).
} 
income groups shown already in Fig. 3, and now in Fig. 4. Both portrayals show that the years of military rule were remarkably favorable to top income groups and unfavorable to the bottom, relative to the earlier and later regimes of democratically elected governments. Adding taxes into the picture shows an additional reason why: the top $20 \%$ got a relative tax break, one that was largely reversed by the concertación government starting in 1991, as is also clear in Figs. 3 and 4.

Chile's shift toward more progressive redistribution, and lower post-fisc inequality, since 2000 has been widely noted. ${ }^{24}$ Our Figs. 3 and 4 confirm the rise in redistributive progressivity. The middle income groups regained a net positive fiscal effect across the 1990s, and the poorest quintile gained positive redistribution from 2005 on. The underlying mechanism, while not entirely clear, seems to have worked mainly on the tax side. Direct tax collections rose considerably as a share of government revenue, while the value added tax dropped. Given that the former fall mainly on the top quintile and the latter are neutral or slightly regressive, the revenue shift should have been progressive, as our figures imply.

\subsubsection{Argentina Since World War II}

Argentina's commitment to social spending gained steam during Perón's administration with expansion of education and social security; however, these policies were consolidated in later decades, as social spending became a larger share of the budget. This evolution was far from steady, as the Argentine economy failed to achieve stable economic growth. The social welfare state suffered a setback in the late 1970 s with a sharp impact on the social security and labor market programs paired with a more regressive taxation system. Employer contributions were seen as detrimental to the private sector's competitiveness, resulting into their subsequent abolition. With lower direct tax collection and increasing inflation tax, the net benefits of the bottom quintile stagnated at best. From the 1980s onwards, while social spending increased in terms of GDP, this rise was far from stable. Social spending has been more volatile than GDP growth and has run pro-cyclically. This combination has eroded its effectiveness as progress in education and health requires sustainable social spending. That said, the sheer magnitude of Argentina's tax effort on behalf of social spending, as a share of GDP, jumped far ahead of Chile's in the 1990s, under Menem. Argentina's greater social spending share has not fallen back in the twenty-first century, despite the depth of the 2001 crash and the steepness of the subsequent recovery.

State-induced redistribution. With the advent of populism in Argentina, income redistribution towards the popular class became a priority for the new government. Under Perón's initial presidencies (1946-1955), the public sector quickly expanded

\footnotetext{
${ }^{24}$ For example, see Chile's redistribution coefficients in global perspective in Solt $(2009,2014)$. Rodriguez Weber (this volume) finds a leveling in pre-fisc labor earnings from 1988 to 2000, but no pre-fisc leveling after 2000. Combining his result with the others would suggest, again, a shift toward progressive redistribution after 2000.
} 
with the proliferation of ministries and the takeover of public utilities. ${ }^{25}$ Social spending followed the trend, with education rising from $6 \%$ of the budget to nearly $15 \%$ by the end of the term. This commitment to education translated into a rise in enrollment reaching $50 \%$ of the children in schooling age, a net 12-percentagepoint increase from 1945 (Véganzonès and Winograd 1997). While education was an important component of social spending before 1970, the expansion of the pension system's coverage turned into an important source of benefits, mostly to the urban population. ${ }^{26}$ The redistributive efforts worked, as wage earners' GDP share climbed ten percentage points by 1954 to reach over $48 \%$ of GDP by $1954 .{ }^{27}$ This impressive gain, however, was mostly due to public credit policies increasing monetary wages, including a very popular innovation of the compulsory Christmas bonus (the "Aguinaldo"). ${ }^{28}$ Taking advantage of the taxation infrastructure established in the 1930s, the government expanded taxation by increasing rates . Faced with insufficient revenue, sales taxes rose from 1.25 to $8 \%$ while profit and export taxes were also targets (Blanco 1956; Gerchunoff 1989). Later, the government attempted to ameliorate the regressive character of the tax system by decreasing taxes of basic necessities (Banco Central 1955).

More significant was the progressive role of the income tax (see Fig. 5). The top rates were increased from 7 to $22 \%$ in 1942 to be revised again a decade later (Alvaredo 2007). Income tax collection grew accordingly reaching $2.7 \%$ of GDP during the Peronato compared to $0.7 \%$ during the previous decade.

The revenue-enhancing reforms failed to cover the growing public expenditure, and the government resorted to tapping social security funds. The growing imbalance of the fiscal accounts translated into inflation, reaching nearly $10 \%$ of GDP in 1949. Though it decreased subsequently, the inflation tax was to remain a feature in the fiscal and daily lives of Argentina.

Consolidation and retreat of social spending with less progressive taxation, 19551989. Life after Perón was plagued with sudden changes in economic policy. The intermittent and interrupted long-term and stabilization programs hampered economic growth. In terms of social spending, the central government devoted considerable resources in the 1960s and 1970s to reach around $10 \%$ of GDP, and over $25 \%$ for all levels of government combined. Social assistance transfers (pensions and "other") represented nearly $40 \%$ of all social spending by the central government. Progressive taxation remained in place for another decade post Perón but it had unraveled by mid-1970s with a substantial decrease in direct taxes as a source of revenue. ${ }^{29}$

\footnotetext{
${ }^{25}$ Moreover, an increasing share of public expenditure was off the treasury records such as state railroads, the trade institute (IAPI), and the national mortgage bank.

${ }^{26} \mathrm{By}$ the turn of the twentieth century, the pension system in Argentina included only public employees. Before Peronist times, the system expanded to include employees from banking, insurance, press, and naval and air transportation (Arza 2010).

${ }^{27}$ Estimations based on CEPAL (1958) considering only salaries.

${ }^{28}$ Established by Decree number 33.302/45. Technically, this extra salary was established before Perón's presidencies; however, the origin of this idea is traced to Perón's stint as Secretary of Labor between 1943 and 1945.

${ }^{29}$ Again see Fig. 5. Gaggero (2008) maintains that the elites and their short-run macroeconomic policies are to blame for this development.
} 


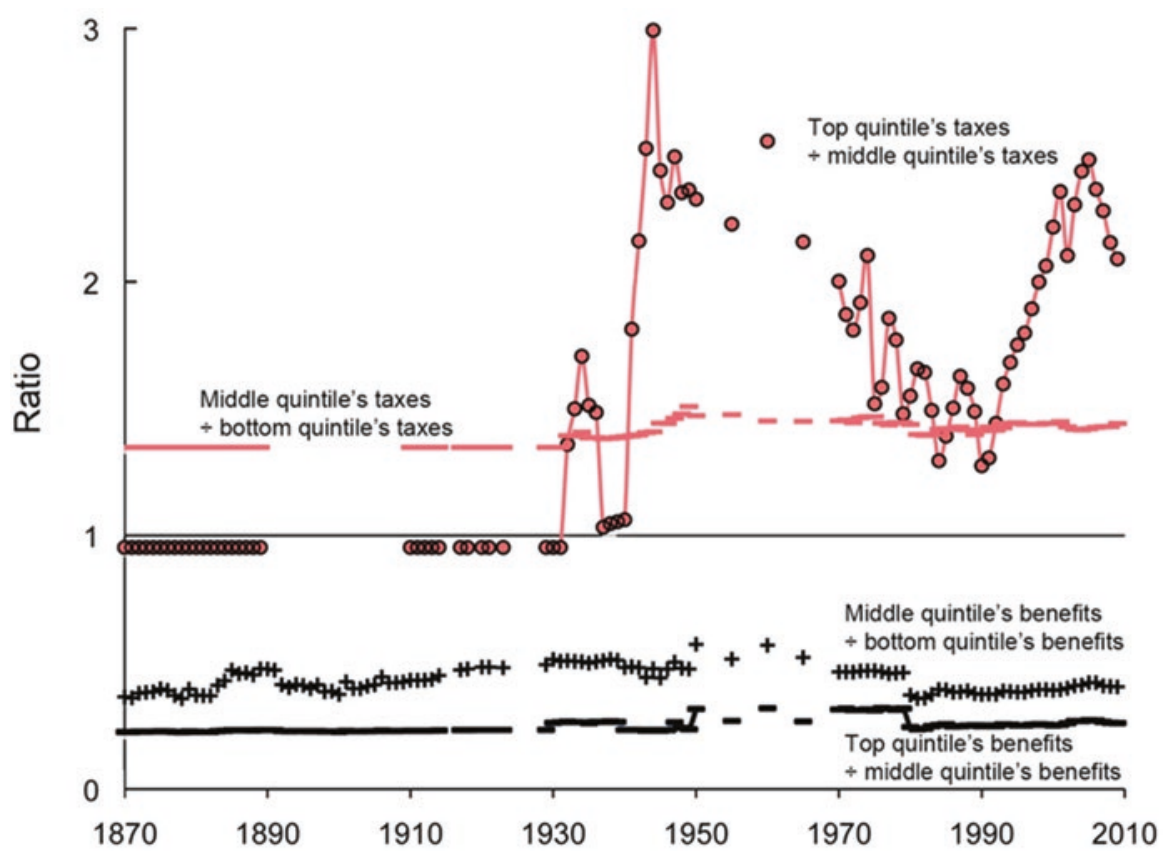

Fig. 5 Benefits of social spending, rich vs. middle vs. poor, Urban Argentina, 1870-2009. Sources and notes: see Appendix 1

Curiously the military governments did not eradicate the welfare state introduced by Perón, but consolidated it with an array of inefficient policies within the framework of a state-oriented economy. ${ }^{30}$ Dubbed as paternalistic and rooted in Catholic views of a more unified society, the state expanded social security to include a new national housing system (FONAVI) funded by employers' tax contributions. However, this expansion was short-lived. In 1979 the employers' contributions are abolished, defunding the pension system and the public housing program. This sharp turn in social policy reduced the relative benefits of the top and middle quintiles as shown in Fig. 5. This slash of the benefits was outweighed by the government's rising use of the sales tax to recoup revenue (Marshall 1988). With inflation graduating from moderate to high (and even reaching hyperinflation in 1989 and 1990), the taxation system turned much more regressive. ${ }^{31}$ For the 1980s, the inflation tax incidence on wage earners hovered around 2.2 to nearly $6 \%$ of GDP per year. However, the impact was 3:1 when comparing the first to the fifth quintile, making the tax incidence more regressive due to the increasing monetization of the fiscal

\footnotetext{
${ }^{30}$ Franco (1992) claims that the social policies in Latin America during this period were useless as they only granted segmented access and excluding universalism.

${ }^{31}$ As our estimations for relative tax incidence are based on 2009 figures, the impact of inflation tax is absent. Given its regressive nature, our estimates of tax incidence for the late 1980s most likely appear more progressive than they probably were.
} 


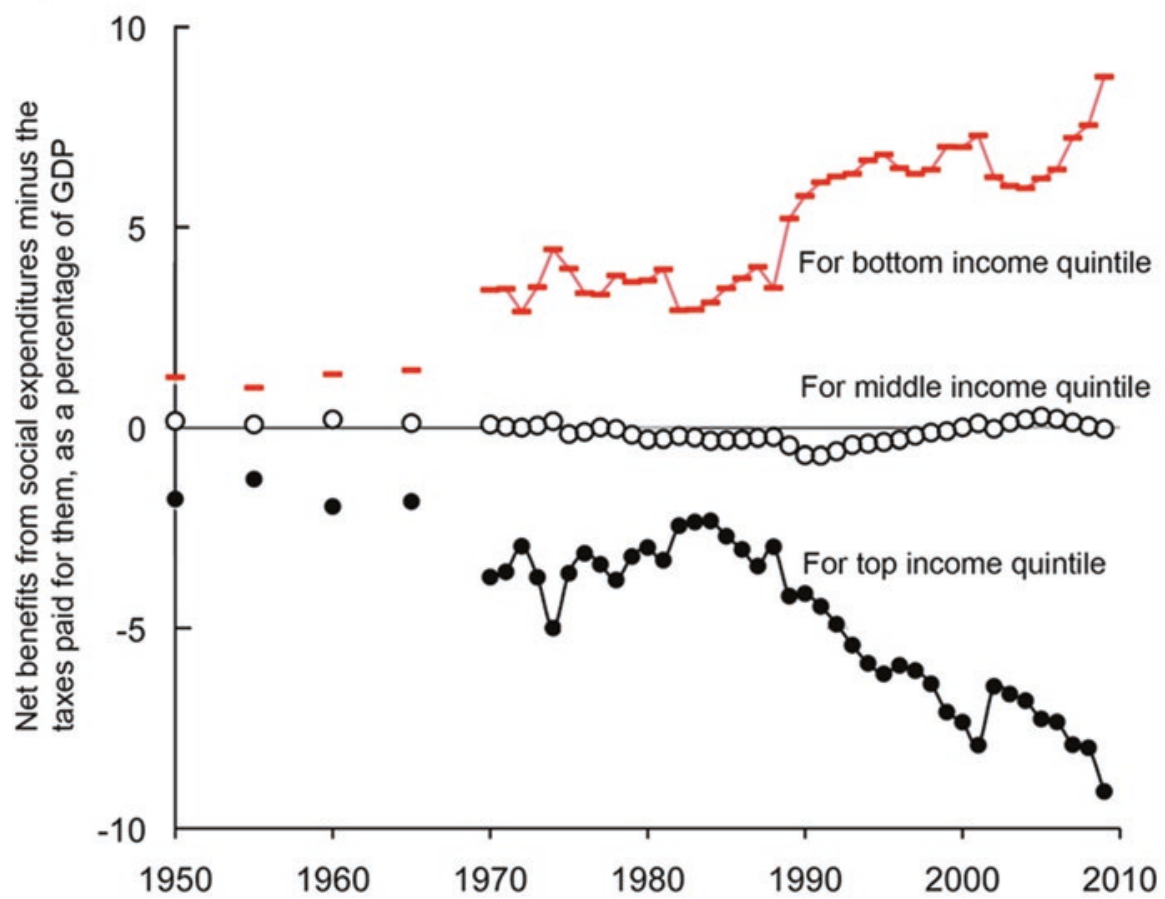

Fig. 6 Net Benefits minus taxes paid, on social spending by consolidated government, Argentina 1970-2009. Sources and notes: see Appendix 1

deficit (Ahumada et al. 1993). Figure 6 shows the regressive net effect of this combination in the 1980s.

The rise of social spending along with changes in taxation, 1990-2013. Since 1992 Argentina's social spending has been more volatile, pro-cyclical-and more progressive, as shown in Figs. 5 and 6. Spending on social security has expanded, and the pension system alone reached almost $74 \%$ of total spending in 2013 . This time, however, the rise in pensions was progressive. The extension of coverage and the rise in social security paychecks explains most of this increase. Consistent with the retreat of post-fisc inequality observed in the 2000s, the net fiscal benefits for the bottom quintile increased substantially to nearly reach $5 \%$ of GDP. ${ }^{32}$ On the taxation side, the Menem government introduced a two-sided change. On the regressive side, it relied more on the value-added tax with rates climbing to $21 \%$ while the income tax rate for the top bracket was reduced to $33 \%$ in 1997 (to be increased

\footnotetext{
${ }^{32}$ On volatility and pro-cyclicality, the correlation between real GDP and real social spending is above 0.8 for using both central and total government spending. When testing changes in real GDP vs. changes in real social spending the coefficient drops to 0.5 . The volatility of real social spending relative to real GDP (measured as the standard deviation of the annual real changes) is three times higher.
}

On the changes in the design of social security, see Selva and Iñiguez (2009). 
2 percentage points 3 years later). Yet at the same time, it improved tax collection by reducing evasion. This latter, progressive, side of the coin takes on a strong form in our Figs. 5 and 6, which show a trend toward progressivity shared by the otherwise very different presidencies from Menem to the Kirschners.

The impact of this mix actually worsened inequality in the late 1990s, according to CEPAL estimates. ${ }^{33}$ Still, the expansion of social spending with an increase of overall tax collection gave rise to a more progressive fiscal redistribution since 1992.

\subsubsection{Uruguay, the Social Spending Leader Over the Last 100 Years}

Though the region has lagged in public education spending ever since Independence, Uruguay was an early leader in education levels, helped by its initially high income (Lindert 2010; Rodriguez Weber and Thorp 2013). Its commitment to primary and secondary education did not flag, although Chile and Argentina caught up by the 1930s.

In terms of social assistance, the 1930s saw a jump, due to enlarging the social security system, and to expanding the pension system to cover workers in the formal industry and commerce sectors.

What shows up even more clearly in the history of social spending is a consistent Uruguayan tendency toward equalizing incomes. As shown in Fig. 7, Uruguay's

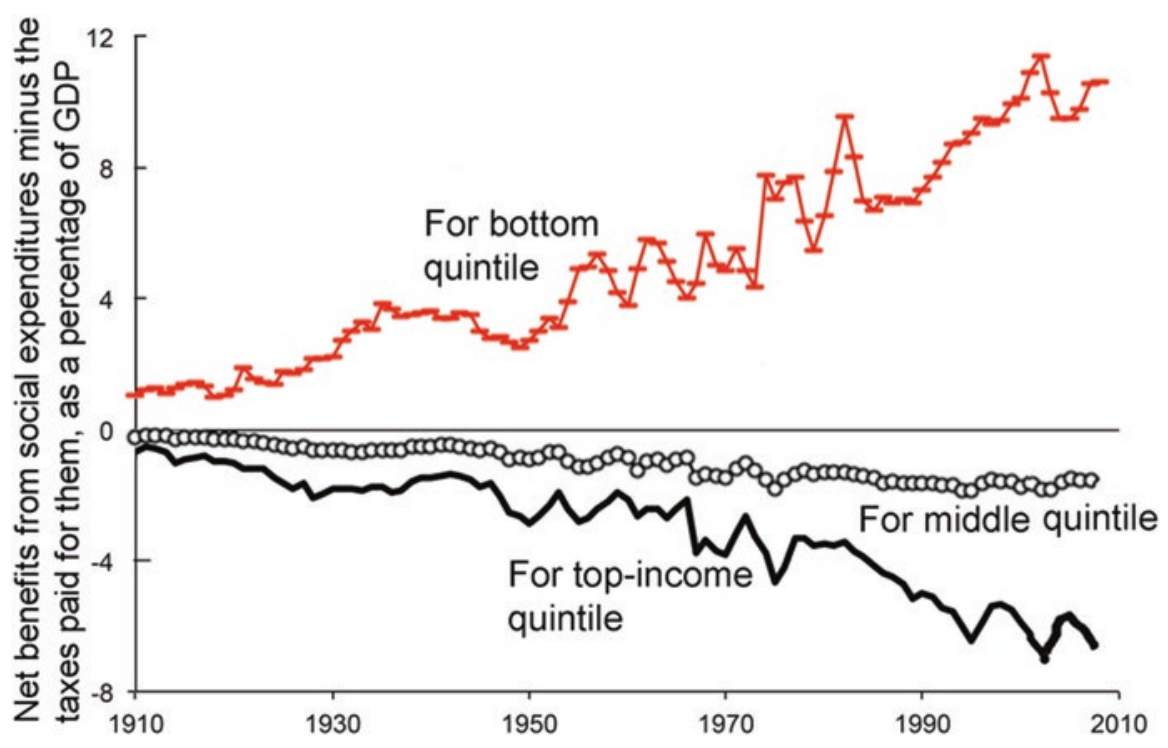

Fig. 7 Benefits of social spending benefits minus taxes for them, rich vs. middle vs. poor, Uruguay 1910-2008. Sources and notes: see Appendix 1

${ }^{33}$ Cetrángolo and Gómez-Sabaini (2006). 
social spending has been highly progressive throughout the last 100 years. The long rise of the redistribution in terms of GDP, so conspicuous in Fig. 7, is due mainly to the expansion in the size of social budgets, rather than to any shift toward greater unit progressivity of social programs. For at least a 100 years Uruguay has had a more progressive mix of social programs than in Chile. ${ }^{34}$ Certainly the mix is more progressive today, as Table 5 testifies.

One potential interruption to the upward march of social spending came with military rule in 1973-1985. In this respect Uruguay's time path could have resembled that of Chile and Argentina. Yet in Uruguay the military rule did not reverse either the expansionary trend or the progressivity of social programs, as evident in Fig. 7. Thus Uruguay stands out as the region with the longest-standing trend toward progressive redistribution.

\subsubsection{Colombia-Half Progressive, Half Regressive}

Colombia's patterns of fiscal incidence are decidedly mixed, according to two studies of social spending and taxes in the 1960s and 1970s. On the one hand, public primary education and all rural public services have been progressive, even in the "clearly progressive" sense delineated in Table 3 above. Subsidies to university education were highly regressive, in Colombia as elsewhere, although the magnitude of university subsidies was small in relation to the amounts given out in the other programs. Also regressive were urban public services. On balance, the entire fiscal system seems to have redistributed only a small share of national income, perhaps $1.4 \%$, from the top quintile the other $80 \%$ of the population as of $1966 .{ }^{35}$

On the pension front, once public pensions were started in 1967, Colombia has followed in Chile's footsteps, both in the under-contribution problem inherited by reformers in 1993 and in the regressive deficits that the reforms brought to light. Again, as in Chile, repairing and removing the handover from the previous defined benefit system have proven difficult ever since the reforms were launched, in this case by Law 100 in 1993 . Though the reform tried to set up a pension reserve, it was exhausted as early as 2004. Since the pension system covers only $25-27 \%$ of the labor market, under a dual private-public regressive scheme, the central government has been forced to cover pension deficits out of about a third of its total tax revenues, or nearly $5 \%$ of GDP. As shown in Table 4, Colombia fits the regional pattern of veering toward dominance of non-contributory pensions in its social programs, despite attempts to curb this tendency. ${ }^{36}$

\footnotetext{
${ }^{34}$ Azar et al. (2009) and Rodriguez Weber and Thorp (2013).

${ }^{35}$ For Colombia 1966, the main source is Berry and Urrutia (1976). Estimates covering the expenditure side for Colombia in 1974 are found in Selowsky (1979). For the net result in 1966, see Table 5.

${ }^{36}$ Clavijo 2009, pp. 3-14.
} 


\subsubsection{Costa Rica Since the 1940s}

As the available numbers in Table 4 suggest, Costa Rica has had a steadier growth of social spending than some of the other countries.

As compared with Uruguay, Costa Rica redistributes less progressively each year, in the sense of reducing the Gini coefficient of inequality. Yet as of 2003, it has achieved greater equality of final income, and also greater equality of original (market, or pre-fisc) income. How? The contrast can have many explanations, including the countries' fortunes in international trade. One element of social policy seems to have contributed. Since at least 1900, Costa Rica has poured a greater share of national product into public primary and secondary education than has Uruguay, and the difference persists in this century. Its broader skill base has produced more equality in the long run by equalizing basic earning power, thereby achieving a greater reduction in inequality than Uruguay's more ambitious pensions and other transfer payments, even though both have existed since the dawn of the twentieth century. Here again, we must remember that each year's egalitarian investments have a longer lasting, though delayed, effect on equality than that year's expenditures can show.

On the public pension front, Costa Rica started developing its system early. Its pre-1948 institutional innovations became a permanent feature of Costa Rica's equity oriented policy framework, despite the defeat of the system's original designers during the civil war in 1949-1950. Costa Rica has more recently had the same problems of incomplete pension coverage and underfunding as in other countries, but these never became as serious as in Chile or Brazil or Colombia. The guidelines of social policy, like the larger issues of governance, were effectively resolved in the middle of the twentieth century, with a combination of political cooperation, foresight, and a lucky boom in coffee exports. ${ }^{37}$

\subsubsection{Peru Since the 1940s}

Peru has always spent a lower share of GDP on social programs than even Chile, as Table 4 has shown. And on balance, its fiscal redistributions have not yielded any net progressivity. The social policies since the 1940s in Peru have derived from the role that the state played in the economy, swaying from interventionism to (neo) liberalism. The steady growth of social spending since the 1940s was abruptly interrupted with the crisis of the late 1980s, and then resumed in the following decades.

Modest progress under an interventionist state. From 1945 to 1948, the government adopted a pro-distribution stance through income policies (such as price freezes and wage increases) and extension of social policies (including free and universal secondary education and the Sunday wage). The state was seen as a means of economic development and social integration and social spending increased accordingly. With a change to a more liberal regime the government implemented a

\footnotetext{
${ }^{37}$ On the early innovations, see Gonzalez-Vega and Céspedes (1993, pp. 82-85). For an appraisal of Costa Rica's redistributive policies today, see Oviedo et al. (2015, pp. 23-61).
} 
more pragmatic social policy with selected programs in education and health. From a macroeconomic point of view, none of these initiatives amounted to more than $2 \%$ of GDP. The government intervention to foster social progress had limited impact by the early 1960s. While the net benefits were progressive, they did little to overcome the initial market-based inequalities, especially for the rural traditional sector. Confronted with this reality the military government headed by President Velasco (1968-1973) initiated an ambitious plan to redistribute income and wealth. This conscious commitment to redistribution translated into a significant increase in social spending. ${ }^{38}$

Crisis and reform. The 1980s meant a continuous struggle to achieve macroeconomic stabilization resulting in a decrease of social and total public spending culminating in hyperinflationary episodes in 1987-1990. In the following decade the reorganization of the public sector included an expansion of social spending, especially in education and health. That expansion notwithstanding, Peru's fiscal redistribution failed to be progressive overall, as shown by the studies that have led to Table 2.

\section{Summary: What the Emerging Historical Patterns Suggest}

Most countries' social expenditure programs end up redistributing to an intermediate degree - that is, in the intermediate range shown in Table 2. They deliver a greater absolute value of benefits to higher income groups, relative to a flat per capita "poll subsidy." That looks regressive. On the other hand, they deliver rewards that are less unequal than the distribution of original incomes. That means that their expenditure pattern dampens the serious inequalities of original income. This slightly progressive tendency is reinforced by the modest progressivity in tax rates as a share of original market income.

Of the six countries covered here, the two most progressive have been Uruguay and Argentina, which have historically met the standard of absolute progressivity for a few decades. To judge from the region-wide situation at the start of the twentyfirst century, those two countries may have been the only absolutely progressive countries in all of Latin America, aside from Cuba.

To this pattern of only middling progressivity in social programs and taxes, we have added the easily documented tendency of Latin America to redistribute toward the current senior generation by investing little in the younger generations. Over recent decades the countries in the region have increasingly squandered lost economic capital and growth by spending their political capital on subsidizing the older generations with non-contributory public pensions. Of the countries studied here, the Southern Cone has redistributed away from future generations the most, and

\footnotetext{
${ }^{38}$ On social policies up through the 1960s, see Contreras and Cueto (2004) and Webb (1975). President Velasco's wealth redistribution policies included land reform, nationalization, and worker cooperatives (Figueroa 1995).
} 
Costa Rica has done so the least. While Peru and Colombia have also tended to tilt toward pensions, they have done so with smaller overall budgets in relation to GDP, and their regressive side has manifested itself in more conventional ways.

This low-investment tendency has featured a hundred-year history of lower investment in primary and secondary education. The implied prescription is to seize the opportunity, at last, of achieving both more equality and faster growth with broader investments in human skills. In this prescription our study seems to be in accord with the present-day prescription of Augusto de la Torre and co-authors:

"[E]fforts to equalize opportunities for human capital formation, particularly by broadening the access to high quality education regardless of socio-economic background, must be at the core of the search for shared prosperity in [Latin America and the Caribbean]." 39

The region as a whole still has time to reduce the pension deficits that even Chile's reform have not yet tamed. The opportunity is there because the region's populations are still younger than those of the core OECD countries or Eastern Europe. Yet the political will may not be there, in view of how readily the appetite for non-contributory public pensions has grown since the 1960s, and how halfhearted the commitment to public education remains.

Acknowledgements Our historical mapping introduces six cases: Chile, Argentina, Uruguay, Costa Rica, Colombia, and Peru. Other countries are being researched, and will be added in later publications. We are also developing a set of downloadable files, giving supporting data for Figs. 1-14 on the site http://gpih.ucdavis.edu. The authors thank Maria Marcela Harriague, Alejandra Irigoin, Joaquin Marandino Peregalli, Bruno Seminario de Marzi, Juan Diego Trejos, the editors, and conference participants for constructive comments, and the US National Science Foundation for research support under grant SES 1227237.

\footnotetext{
${ }^{39}$ De la Torre et al. (2014, p. 7).
} 


\section{Appendix 1: Data Sources and Notes for Table 4 and Figs. 1, 2, $3,4,5,6$, and 7}

\section{Table 4}

\section{Argentina}

Revenue =1900-1931: Vasquez-Presedo (1971), 1932-1964: AFIP (2009), 1965-2006: Ministerio de Economía y Producción (2006), 2007-2013: AFIP (2010), AFIP (2011), AFIP (2012), AFIP (2013).

Expenditure =1900-1915: Dirección General de Estadística (1915); 1929-1939: Vasquez-Presedo (1971); 1940-1962: Based on national budgets, Infoleg (2014), and IEERAL (1986); 1965-2006: Ministerio de Economía y Producción (2006), Oficina Nacional del Presupuesto (2014).

Nominal GDP=1900-1932: Ferreres (2005); 1932-2013: Ministerio de Economia y Finanzas (2014ab).

\section{Chile}

Revenue and expenditure = until 2000: Díaz et al. (2010); 2000-2013: online data from Banco Central de Chile and Ministerio de Economía.

Nominal GDP=Warner et al. (2000).

\section{Colombia}

Revenue=1900-1920: Departamento Administrativo Nacional de Estadística (1973); 1920-2003: Junguito y Rincón (2007); 2004-2013: Banco Central de Colombia (2014). For detailed data on income and wealth taxes: Anuario de Estadística General, various numbers and Dirección General de Presupuesto Público Nacional (2014).

Expenditure = 1900-1920: Departamento Administrativo Nacional de Estadística (1973); 1920-2003: Junguito y Rincón (2007); 2004-2013: Banco Central de Colombia (2014). For detailed data on public expenditure by type: Anuario de Estadística General, Banco Central de Colombia (1997), Dirección General de Presupuesto Público Nacional (2014).

Nominal GDP=GRECO (1998, 1999) and Banco Central de Colombia (2014). Note that nominal GDP experienced significant increase in the 1990s and over $35 \%$ from 1999 to 2000 due to a change in methodology. For the data series, see in http:// gpih.ucdavis.edu, the folder for "Government budget historical series," under the heading "Latin American fiscal redistribution", the file "Colombia central gov't budgets 1901-2013."

\section{Costa Rica}

Revenue $=1870-1958$ : total public revenue and by type kindly provided by Juan Diego Trejos. According to the tables, the data correspond to central government as reported by Román Trigo (1995). 1959-1970s: total public revenue and by type from Ramírez (1977); 1970-2013: total public revenue and by type from the Ministerio de Hacienda and the Central Bank of Costa Rica. Resource revenue corresponds to taxes on bananas and coffee. 1997-2012: Total revenue (including local government and decentralized units excluding the financial sector): Ministerio de Hacienda. Gobierno General: Ministerio de Hacienda (2014). 
Expenditure $=1870-1958$ : total public revenue and by type kindly provided by Juan Diego Trejos. According to the tables, the data correspond to central government as reported by Román Trigo (1995). 1973-2013: Total and debt expenditure: from the Ministerio de Hacienda and the Central Bank of Costa Rica. 1991-2013: Social expenditure estimated based on CEPAL. 1997-2012: Total expenditure (including local government and decentralized units excluding the financial sector): Secretaría Técnica de la Autoridad Presupuestaria Unidad de Análisis y Seguimiento Fiscal (2014) and Sauma and Trejos (1999).

Nominal GDP and nominal investment $=1950-2003$ : data kindly provided by Juan Diego Trejos; 2004-2014: Central Bank of Costa Rica. Note that the GDP was re-estimated starting in 1991 resulting in a $25-35 \%$ increase in GDP.

For the data series, see in http://gpih.ucdavis.edu, the folder for "Government budget historical series," under the heading "Latin American fiscal redistribution", the file "Costa Rica fiscal 1870-2013."

\section{Peru}

Revenue $=$ Total and composition: 1900-1989: Portocarrero et al. (1992), 19902013: Banco Central de Peru (2014).

Expenditure $=$ Total: 1900-1989: Portocarrero et al. (1992), 1990-2013: Banco Central de Peru (2014). Composition: 1900-1989: Portocarrero et al. (1992); 19702013: Debt payments: Banco Central de Peru (2014); 1998-2013: Education and Health: Ministerio de Economía y Finanzas (2014b), Defense and Pensions: Ministerio de Economía y Finanzas (2014a).

Nominal GDP=1900-1949: Seminario and Beltrán (1998); 1950-2013: Banco Central de Peru (2014).

For the data series, see in http://gpih.ucdavis.edu, the folder for "Government budget historical series,"under the heading" Latin American fiscal redistribution," the file "Peru gov't budgets 1900-2013."

\section{Uruguay}

Revenue, expenditure, and nominal GDP= until 1999 Azar et al. (2009); 20002008 online data from Ministerio de Economia y Finanzas.

Figure 1 (gross capital formation)

The source is World Bank (http://databank.worldbank.org/data/), accessed 13 March 2014.

Figure 2 (education versus pensions)

The sources are as listed for Table 1 .

Figures 3 and 4 (Chile)

The sources for fiscal data and nominal GDP are as listed for Table 4. The estimates of fiscal redistribution have utilized the studies by Engel et al., K. Lindert et al., and Lustig et al., as quantified in http://gpih.ucdavis.edu, the folder for "Government budget historical series," under the heading "Latin American fiscal redistribution," the file "Chile quintile effects 1842-2013."

Figures 5 and 6 (Argentina)

The sources for fiscal data and nominal GDP are as listed for Table 4. The estimates of fiscal redistribution have utilized the studies by Gasparini, Gómez Sabaini et al., Subsecretaria de Coordinación Económica, Lustig et al., SEDLAC, and 
UNU-Wider cited in http://gpih.ucdavis.edu the folder for "Government budget historical series," under the heading "Latin American fiscal redistribution," the file "Argentina fiscal incidence 1870-2009."

The level of government portrayed here varies by parameter and by time period. As far as we can determine from Gasparini (1999) and Lustig (2011), the allocation of recent-benchmark fiscal incidence effects refers to the effects of all consolidated government, not just central government. These recent-benchmark allocations are based on survey data, without any clear distinctions as to the level of government doing the taxing or making the social expenditures. When it comes to the historical fiscal data, however, the scope of government differs as follows:

For 1870-1949, central government budgetary data only

For 1950, 1955, 1960, and 1965, central, provincial, plus municipal governments; and for 1970-2009, consolidated accounts for all levels of government

Figure 7 (Uruguay)

The historical series on social budgets are from Azar et al. (2009). The distribution of household income per capita by decile, year 2000 is from WIID2c, downloaded January 2014, www.wider.unu.edu/research/Database/en_GB/wiid/. The fiscal incidence assumptions are borrowed from Buchele et al. (2013). See the calculations in http://gpih.ucdavis.edu, the folder for "Government budget historical series," under the heading "Latin American fiscal redistribution," the file "Uruguay quintile fiscal effects 1910-2008."

Open Access This chapter is distributed under the terms of the Creative Commons Attribution 4.0 International License (http://creativecommons.org/licenses/by/4.0/), which permits use, duplication, adaptation, distribution and reproduction in any medium or format, as long as you give appropriate credit to the original author(s) and the source, a link is provided to the Creative Commons license and indicate if changes were made.

The images or other third party material in this chapter are included in the work's Creative Commons license, unless indicated otherwise in the credit line; if such material is not included in the work's Creative Commons license and the respective action is not permitted by statutory regulation, users will need to obtain permission from the license holder to duplicate, adapt or reproduce the material.

\section{References}

Abad, L. A. (2013a). Persistent inequality? Trade, factor endowments, and inequality in Republican Latin America. Journal of Economic History, 73.01(March), 38-78.

Abad, L. A. (2013b). Instabilidad, Costo de Vida y Salarios Reales en Venezuela en el Siglo XIX [Instability, Cost of Living, and Real Wages in Venezuela in the 19th Century]. América Latina en la Historia Económica, 20.3(September-December), 114-137.

Acuña Rodrigo, R., \& Augusto Iglesias, P. (2001). Chile's pension reform after 20 years. World Bank, Social Protection Discussion Paper 0129 (December).

Administración Federal de Ingresos Públicos (AFIP). (2007-2013). Anuario Estadísticas Tributarias. Retrieved October 12, 2014 from http://www.afip.gob.ar/estudios/anuario.asp. 
Ahumada, H., \& Canavese, A., Sanguinetti, P., \& Escudero, W. S. (1993). Efectos distributivos del impuesto inflacionario: una estimación para el caso argentino. Economía Mexicana, II(2), 329-383.

Alvaredo, F. (2007). The rich in Argentina over the twentieth century: From the conservative republic to the Peronist experience and beyond 1932-2004. Paris School of Economics Working Paper 2007-02.

Arza, C. (2010). La política previsional argentina: de la estratificación ocupacional a la individualización de los beneficios. In S. Torrado (Ed.), El costo social del ajuste (1976-2002), Buenos Aires, EDHASA, 2010.

Azar, P., Bertino, M., Bertino, R., Fleitas, S., Garcia Repetto, U., Sanguinetti, C., et al. (2009). ¿De Quiénes, para Quiénes, y para Qué? Las Finanzas Públicas en el Uruguay de Siglo XX. Montevideo: Editorial Fin de Siglo.

Banco Central de Colombia. (1997). Estadísticas Históricas, CD-ROM.

Banco Central de Colombia. (2014). PIB, producción, salarios y empleo. Retrieved November 1 , 2014 from http://www.banrep.gov.co/es/series-estadisticas/see_prod_salar.htm.

Banco Central de la República Argentina. (1955). Memoria. Buenos Aires: BCRA.

Banco Central de Venezuela. (2014). Agregados Macroeconómicos. Retrieved November 1, 2014 from http://www.bcv.org.ve/c2/indicadores.asp.

Berry, R. A., \& Urrutia, M. (1976). Income distribution in Colombia. New Haven: Yale University Press.

Blanco, E. A. (1956). La política presupuestaria, la deuda pública y la economía nacional. Buenos Aires: Ministerio de Hacienda de la Nación.

Braceda, K., Rigolini, J., \& Saavedra, J. (2009). Latin America and the social contract: Patterns of social spending and taxation. Population and Development Review, 35(4), 721-748.

Buchele, M., Lustig, N., Rossi, M., \& Amábile, F. (2013, January). Social spending, taxes, and income redistribution in Uruguay. Commitment to Equity Working Paper No. 10.

Central Bank of Costa Rica. (2014). Indicadores Económicos. Retrieved October 21, 2014 from http://www.bccr.fi.cr/indicadores_economicos_/finanzas_publicas.html.

CEPAL [United Nations, Economic Commission for Latin America and the Caribbean (ECLAC)]. (1958). El desarrollo económico de la Argentina. Santiago de Chile: CEPAL.

Cetrángolo, O., \& Gómez-Sabaini, J. C. (2006). Tributación en América Latina. En busca de una nueva agenda de reformas. Santiago de Chile: CEPAL.

Chenery, H., Ahluwalia, M., Bell, C., Duloy, J., \& Jolly, R. (1974). Redistribution with growth. London: World Bank and the Institute of Development Studies, University of Sussex by Oxford University Press.

Clavijo, S. (2009, March). Social security reforms in Colombia: Striking demographic and fiscal balances. IMF Working Paper WP/09/58.

Clemens, M.B., Faircloth, C., \& Verhoeven, M. (2007). Public expenditure in Latin America: Trends and key policy issues. IMF Working Papers WP/07/21.

Cohen, D., \& Soto, M. (2007). Growth and human capital: Good data, good results. Journal of Economic Growth, 12(1), 51-76.

Contreras, C., \& Cueto, M. (2004). Historia del Perú contemporáneo. Lima: Universidad del Pacífico.

Cruz-Saco, M. A., \& Mesa-Lago, C. (1998). Do options exist? The reform of pension and health care systems in Latin America. Pittsburgh: University of Pittsburgh Press.

de la Torre, A., Yeyati, E. L., Beylis, G., Didier, T., Castelán, C. R., \& Schmukler, S. (2014). Inequality in a lower growth Latin America. LAC Semiannual Report (October). Washington, DC: World Bank.

DeFerranti, D., Perry, G. E., Ferreira, F. H. G., \& Walton, M. (2004). Inequality in Latin America: Breaking with history? Washington: World Bank.

Díaz, J., Lüders, R., \& Wagner, G., \& La República en Cifras (2010). EH Clio Lab-Iniciativa Científica Milenio. Retrieved from http://www.economia.puc.cl/cliolab.

Dirección General de Estadística. (1915). Extracto estadístico de la República Argentina. Buenos Aires: Compañia Sud-Americana de Billetes de Banco. 
Dirección General de Presupuesto Público Nacional. (2014). Bitácora Cifras Presupuestales. Retrieved November 5, 2014 from http://www.minhacienda.gov.co/HomeMinhacienda/politicafiscal/GobiernoNacionalCentralGNC/Tab.

ECLAC. (2014). Compacts for equality: Towards a sustainable future. Santiago: United Nations.

ECLAC [United Nations, Economic Commission for Latin America and the Caribbean (or CEPAL)]. (2012). Structural change for equality: An integrated approach to development. Santiago: United Nations.

Engel, E. M. R. A., Galetovic, A., \& Raddatz, C. E. (1999). Taxes and income distribution in Chile: Some unpleasant redistributive arithmetic. Journal of Development Economics, 59, 155-192.

Felipe Portocarrero, S., Arlette Beltrán, B., \& Maria Elena Romero, P. (1992). Compendio estadistico del Peru, 1900-1990. Lima: Universidad del Pacífico.

Ferreres, O. J. (2005). Dos siglos de economía Argentina, 1810-2004: historia Argentina en cifras. Buenos Aires, Argentina: Editorial El Ateneo.

Figueroa, A. (1995). La cuestión distributive en el Perú. In J. Cotler (Ed.), Perú, 1964-1994. Lima: IEP.

Franco, R. (1992). Nuevas orientaciones de la política social en América Latina. CEPAL. Retrieved November 1, 2014 from http://repositorio.cepal.org/handle/11362/18993.

Gaggero, J. (2008). La progresividad tributaria: su origen en Occidente, su apogeo y extravío en Argentina y los desafíos de hoy. Paper presented the the XXI Jornadas de Historia Económica, Caseros, Buenos Aires, Argentina.

Gerchunoff, P. (1989). Peronist economic policies, 1946-1955. In G. di Tella \& R. Dornbusch (Eds.), The political economy of Argentina, 1946-83. Pittsburgh: Pittsburgh University Press.

González-Vega, C., \& Céspedes., V. H. (1993). Part I. Costa Rica. In S. Rottenberg (Ed.) Costa Rica and Uruguay (pp. 3-185). Oxford: Oxford University Press for the World Bank.

GRECO. (1998). El crecimiento económico colombiano en el siglo XX: aspectos globales. Documento de Trabajo del Banco Central de Colombia.

GRECO. (1999). El desempeño macroeconómico colombiano, series estadísticas. Documento de Trabajo del Banco Central de Colombia.

Hertz, T., Jayasundera, T., Piraino, P., Selcuk, S., Smith, N., \& Verashchagina, A. (2007). The inheritance of educational inequality: International comparisons and fifty-year trends. The B.E. Journal of Economic Analysis \& Policy, 7(2), Article 10.

IEERAL. (1986). Estadísticas de la evolución económica de Argentina, 1913-1984. Estudios 9(36).

InfoLeg. (2014). Presupuestos Nacionales. Retrieved 07/2014-11/2014 from http://infoleg.mecon. gov.ar/?page_id=837.

Junguito, R., \& Rincón, H. (2007). La política fiscal en el siglo XX en Colombia. In J. Robinson, \& M. Urrutia (Eds.), Economía Colombiana del Siglo XX: Un Análisis Cuantitativo. Colombia: Banco de la República y Fondo de Cultura Económica.

Lee Hansen, H. W., \& Weisbrod, B. A. (1969). The distribution of costs and direct benefits of public higher education: The case of California. Journal of Human Resources, 4(2), 176-191.

Lindert, P. H. (2010). The unequal lag in Latin American schooling since 1900: Follow the money. Revista de Historia Económica, 28(2), 375-405.

Lindert, K. A.,Skoufias, E., \& Shapiro, J. (2006, August). Redistributing income to the poor and the rich: Public transfers in Latin America and the Caribbean. World Bank, SP Discussion Paper 0605.

Lustig, N., Molina, G., Paz, V., Pereira, C., Scott, J., Pessino, C., et al. (2011, November). Fiscal policy and income redistribution in Latin America: Challenging the conventional wisdom. Tulane University Economics Working Paper 1124 (October). Also EcIneq Working Paper 227.

Marshall, A. (1988). Políticas sociales: el modelo neoliberal. Argentina (1976-1983). Buenos Aires: Editorial Legasa.

Ministerio de Economía, \& Finanzas y Banca Pública. (2014). Estadísticas Fiscales. Retrieved November 7, 2014 from http://www.mefbp.gob.ve/index.php?option=com_content\&view=arti cle\&id=245\&Itemid $=381$. 
Ministerio de Economía y Finanzas. (2014). Estadísticas. Retrieved November 5, 2014 from https://mef.gob.pe/index.php?option=com_content\&view=article\&id=364\&Itemid=100292\&1 ang=es.

Ministerio de Economía y Finanzas. (2014). Gasto Social Público. Retrieved November 7, 2014 from http://www.mef.gob.pe/index.php?option=com_content\&view=article\&id=280\&Itemid $=100850$ \&lang=es.

Ministerio de Economía y Producción. (2006). Presupuesto de la Administración Nacional: Gastos por Finalidad-Función y Naturaleza Económica, 1965-2006. Buenos Aires: Ministerio de Economía y Producción.

Ministerio de Hacienda. (2014). Cifras Fiscales y Estadísticas. Retrieved October 21, 2014 from http://www.hacienda.go.cr/contenido/698-gobierno-central.

Oficina Nacional del Presupuesto (2014). Series estadísticas, Administración Nacional por Finalidad-Función y Naturaleza Económica, 2007, 2008, 2009, 2010, 2011, 2012, 2013. Retrieved November 1, 2014 from http://www.mecon.gov.ar/onp/html/\#.

Olviedo, A. M., Sanchez, S. M., Lindert, K. A., \& Humberto Lopez, J. (2015). Costa Rica's development: From good to better. Washington: World Bank Systematic Country Diagnosis.

Pallares-Miralles, M., Romero, C., \& Whitehouse, E. (2012, June). International patterns of pension provision II: Worldwide overview of facts and figures. World Bank Social Protection \& Labor Discussion Paper 1211.

Public Finance Review. (2014, May). 42(3). Special Issue: Analyzing the Redistributive Impact of Taxes and Transfers in Latin America.

Ramírez, E. (1977). Los ingresos corrientes del Gobierno Central un análisis econométrico 19501975, UCR/IICE.

Reimers, F. (2006). Education and social progress. In V. Bulmer-Thomas, J. H. Coatsworth, \& R. Cortés Conde (Eds.), The Cambridge economic history of Latin America (Vol. II, pp. 427480). Cambridge: Cambridge University Press.

Rodriguez Weber, J., \& Thorp, R. (2013). The political economy of (re)distribution with low growth: Uruguay 1900-1973. As downloaded, 14 December, 2013. Las XXVIII Jornadas Anuales de Economía, Banco Central del Uruguay, Montevideo 8 de noviembre de 2013.

Román Trigo, A. C. (1995). Las finanzas públicas de Costa Rica: Metodología y Fuentes (18701948). Serie de Trabajos de Metodología, 3.

Rottenberg, S. (Ed.). (1993). Costa Rica and Uruguay. Oxford: Oxford University Press for the World Bank.

Sauma, P., \& Trejos, J. D. (1999). Costa Rica. In L. C. Delgado, C. E. Reyes Gonzalo, \& A. Sarmiento Gómez (Eds.), Gasto Público en Servicios Sociales Básicos en América Latina y el Caribe: análisis desde la perspectiva de la iniciativa 20/20. Santiago de Chile: CEPAL.

Sauma, P., \& Trejos, J. D. (2014, March). Social public spending, taxes, income, and poverty in Costa Rica. Commitment to Equity Working Paper No. 18.

Secretaría Técnica de la Autoridad Presupuestaria Unidad de Análisis y Seguimiento Fiscal. (2014). Consolidación por Clasificación Funcional. Retrieved October 31, 2014 from http:// www.hacienda.go.cr/docs/545165afe3643_FUNCIONAL\%202013\%20PARA\% 20 PUBLICAR.pdf.

Selowsky, M. (1979). Who benefits from government expenditure? A case study of Colombia. Oxford: Oxford University Press for the World Bank.

Selva, R., \& Iñiguez, A. (2009). Descripción de la evolucióndel Gasto Público Consolidado del Sector Público Argentino: 1980-2008. Buenos Aires: Ministerio de Economía.

Seminario, B., \& Beltrán, A. (1998). Crecimiento económico en el Perú, 1896-1995: nuevas evidencias estadísticas. Lima, Perú: Universidad del Pacífico, Centro de Investigación.

Sokoloff, K., \& Zolt, E. M. (2006). Inequality and taxation: Evidence from the Americas on how inequality may influence tax institutions. Tax Law Review, 59, 201-276.

Solt, F. (2009). Standardizing the world income inequality database. Social Science Quarterly, 90(2), 231-242.

Solt, F. (2014). The standardized world income inequality database. frederick-solt@uiowa.edu. Retrieved from October 2, 2014. 
Székely, M., \& Montes, A. (2006). Poverty and inequality. In V. Bulmer-Thomas, J. H. Coatsworth, \& R. Cortés Conde (Eds.), The Cambridge economic history of Latin America (Vol. II, pp. 585-645). Cambridge: Cambridge University Press.

Vasquez-Presedo, V. (1971). Estadisticas Historicas Argentinas (comparadas), Premier Parte $1875-1914$.

Véganzonès, M.-A., \& Winograd, C. (1997). Argentina in the 20th century: An account of long-awaited growth. Paris: OECD.

Velez-Grajales, R., Campos-Vazquez, R., \& Huerta-Wong, J. E. (2014). Report on social mobility in Mexico: Imagine your future. Mexico: The Espinosa Yglesias Research Centre (ceey).

Wang, C., Caminada, K., \& Goudswaard, K. (2012). The redistributive effect of social transfer programmes and taxes: A decomposition across countries. International Social Security Review, 65(3), 27-48.

Webb, R. (1975). Políticas gubernamentales y distribución del ingreso en el Perú, 1962-1971. In R. Webb \& A. Figueroa (Eds.), Distribución del ingreso en el Perú. Lima: IEP.

Williamson, J. G. (2010). Five centuries of Latin American inequality. Revista de Historia Económica., 28(2), 227-252.

Leticia Arroyo Abad is an associate professor of Economics at Middlebury College. Her research agenda looks at development and growth in historical perspective. With special focus on Latin America, she explores topics related to inequality, living standards, and economic growth. Her work was published in academic journals such as the Journal of Economic History, Explorations in Economic History, and the Journal of Iberian and Latin American Economic History.

Peter H. Lindert is an economic historian, Distinguished Research Professor of Economics at the University of California-Davis, and a Research Associate of the National Bureau of Economic Research. His works on the welfare state and inequality include his prize-winning book Growing Public: Social Spending and Economic Growth since the Eighteenth Century (Cambridge University Press 2004) and his book Unequal Gains: American Growth and Inequality since 1700 (Princeton University Press 2016), coauthored with Jeffrey Williamson. 